\title{
FORM OVER SUBSTANCE? THE VALUE OF CORPORATE PROCESS AND MANAGEMENT BUY-OUTS
}

\author{
By MATTHEW D. CAIN" \& STEVEN M. DAVIDOFF**
}

\begin{abstract}
We examine management buy-out ("MBO") transactions announced from 2003-2009 in order to study the wealth effects of MBOs and the role of process. We find that there is "value" in corporate process. MBO offer premiums are positively associated with competitive contracts and the existence of special committees. Among transactions with low initial offer premiums, bid failures are more likely when target shareholders benefit from competitive contracts. Our results allow for a cautious approach and more rigorous application of current Delaware law to provide that courts more vigorously scrutinize MBO transactions. They also inform the proper standard for review of other forms of takeovers with explicit agency/principal conflicts, including freeze-outs.
\end{abstract}

\section{TABLES OF CONTENT}

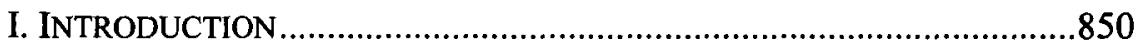

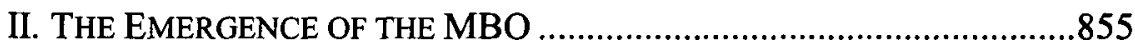

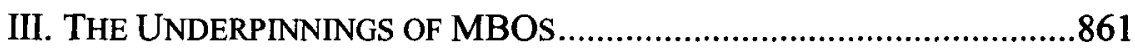

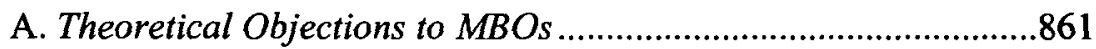

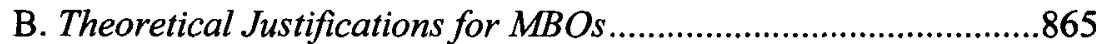

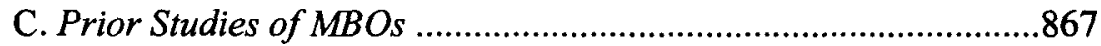

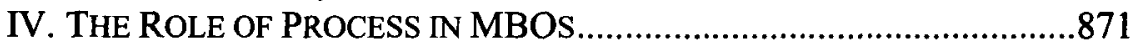

A. The Regulation of Conflicts in Takeovers ..................................871

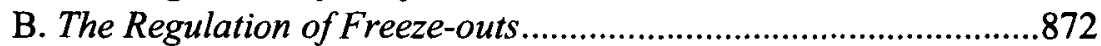

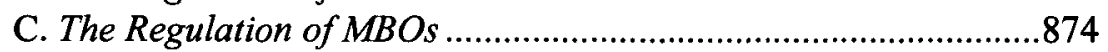

D. Normative Protections in MBO Transactions ..............................876

Assistant Professor of Finance, University of Notre Dame.

"Associate Professor of Law, Moritz College of Law, Fisher College of Business (by courtesy), Ohio State University. We would like to thank Chancellor William B. Chandler, III, Chancellor Leo E. Strine, Jr., Christine Sautter, George Geis, Charles Whitehead, and Charles Yablon as well as attendees at the Yale Law School 2010 Conference on Empirical Legal Studies, the 2010 Southeastern Association of Law Schools (SEALS) conference and the Delaware Journal of Corporate Law symposium "Irreconcilable Differences: Director, Manager and Shareholder Conflicts in Takeover Transactions" for their helpful comments and suggestions. The authors would also like to thank Margaret Budnik, Steven Camerota, and B.J. Pivonka for their research assistance. 
V. THE ROLE OF PROCESS IN MBOS (2003-2009) ………....................879

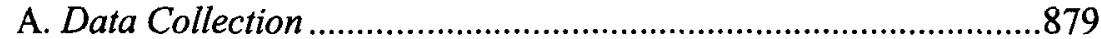

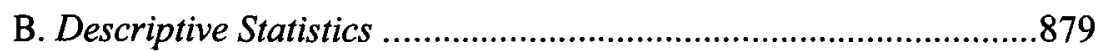

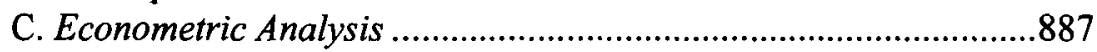

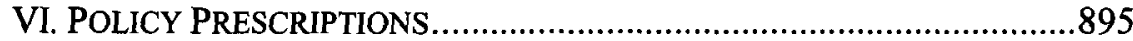

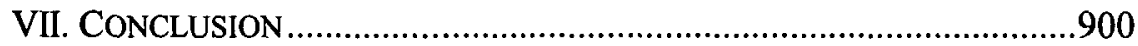

\section{INTRODUCTION}

On July 22, 2009, Bankrate Inc. ("Bankrate") announced that a consortium consisting of seven members of its management, two of its board members, and the private equity firm Apax Partners, would partner to acquire Bankrate in a transaction valued at $\$ 571$ million.' SEC filings would later disclose that the process had begun three months prior when senior Bankrate management had suggested that a sale be explored. ${ }^{2}$ Two prespecified private equity firms were subsequently contacted. ${ }^{3}$ The sale process was confined at management's suggestion to these two bidders. ${ }^{4}$ When one of the private equity firms declined to bid for the entire company, management focused its negotiations on Apax, who at the last minute lowered its (and management's) offer. ${ }^{5}$

The transaction came under heavy criticism for both a low premium and management's role in manipulating and controlling the sale process to their benefit. ${ }^{6}$ Experts and proxy advisory services particularly focused on the board's failure to cleanse the management conflict by not running an active bidding process, forming a special committee, retaining independent advisors, or inserting in the merger agreement a condition that the transaction be approved by a majority of the minority shareholders. ${ }^{7}$ The

'See Kathy Shwiff, Apax Deal: Bankrate Goes Private, WALL ST. J., July 23, 2009, at C3; Bankrate, Inc., Amendment No. 4 to Schedule 14D-9 (Form SC 14D9/A), at 18 (Aug. 24, 2009), available at $\mathrm{http}: / / \mathrm{www}$. sec.gov/cgi-bin/srch-edgar (search "FILM-NUMBER=091029579"; set "Start" to "2009").

${ }^{2}$ See Bankrate, Inc., supra note 1, at 8-14.

${ }^{3} I d$. at 9.

${ }^{4} I d$.

${ }^{5}$ See id. at 8-14.

${ }^{6}$ See Steven M. Davidoff, Apax Wins Bankrate, Barely, N.Y. TiMEs DEALBOOK (Aug. 27, 2009, 1:59 PM), http://dealbook.blogs.nytimes.com/2009/08/27/apax-wins-bankrate-barely/; Bankrate, Inc., Schedule 13D (Form SC 13D/A), at 5-7 (Aug. 24, 2009), available at http://www.sec.gov/cgi-bin/srch-edgar (search "FILM-NUMBER=091030450"; set "Start" to "2009").

${ }^{7}$ Risk Metrics Group, Inc. (now known as ISS), the most prominent proxy advisory service, recommended against the takeover stating: "A lower takeout price makes lucrative post-closing targets easier to achieve for management, the same management that negotiated the takeout itself." 
transaction was ultimately supported by $52 \%$ of Bankrate's shareholders with shares held by officers and directors comprising $28 \%$ of this number. ${ }^{8}$

Bankrate's board and management likely decided to ignore these normative procedural safeguards since the company was incorporated under Florida law.' A unique Florida statute allowed the Bankrate board to obtain deferential court review of its agreement so long as the disinterested directors approved the transaction. ${ }^{10}$ The procedure that unfolded in the Bankrate transaction would likely not have occurred if the company had been incorporated in Delaware. In Delaware, case law and practitioner norms in reaction thereto have codified certain procedures to be followed when management is involved in a change of control transaction." This includes the formation of special committees and the retention of independent advisors when management is a participant in the acquisition of the company. ${ }^{12}$

The protest over Bankrate's sale process highlights a fundamental area at issue in corporate law: the efficacy and regulation of takeover transactions where management is a principal component of the acquisition group; transactions more commonly known as management buy-outs ("MBOs"). In the 1970 s and 1980 s there was a significant public outcry against MBOs. ${ }^{13}$ Management was accused of utilizing their unique insider position to appropriate private gains at the expense of principal shareholders and overall

Cristina Alesci \& Jonathan Keehner, RiskMetrics Says Bankrate Shareholders Should Reject Apax Offer, BLOOMBERG.COM (Aug. 24, 2009), http://www.bloomberg.co.jp/apps/ news?pid=20670001\&sid=a07TTd04DorE; see also Steven M. Davidoff, Behind the Deal: Bankrate (Again), N.Y. TIMES DEALBOOK, (Aug. 19, 2009, 2:12 PM), http://dealbook.blogs. nytimes.com/2009/08/19/behind-the-deal-bankrate-again/

${ }^{8}$ See Bankrate, Inc., Current Report (Form 8-K) (Aug. 27, 2009), available at http://www.sec.gov/cgi-bin/srch-edgar (search "FILM-NUMBER=091040459"; set "Start" to "2009").

${ }^{9}$ See Intelligent Life Corp., Registration Statement (Form S-1), at Exhibit 3.1 (Mar. 11, 1999), available at http://www.sec.gov/cgi-bin/srch-edgar (search "FILM-NUMBER=99563587"; set "Start" to "1999"). Bankrate, Inc. was formerly known as Intelligent Life Corp. See Bankrate, Inc., Current Report (Form 8-K), at Exhibit 99.1 (Sept. 20, 2000) available at http://www.sec.gov/cgi-bin/srch-edgar (search "FILM-NUMBER=733832"; set "Start" to "2000") (press release).

${ }^{10}$ See FLA. STAT. $\$ 607.0901(4)(a)(2010)$.

${ }^{11}$ See infra Part III.C-D.

${ }^{12}$ See infra Part III.D for a further discussion of these procedures. While these procedural devices are common, the use of other procedural protections in this context differs among Delaware companies. For example, not all of these transactions include a majority of minority approval condition or encompass an active bidding process for the company. See infra Part IV.B for a survey of various $\mathrm{MBO}$ procedures.

${ }^{13}$ See, e.g., Benjamin J. Stein, Shooting Fish in a Barrel: Why Management Always Makes a Bundle in an LBO, BARRON'S, Jan. 12, 1987, at 6, 20 (citing numerous examples of management gains from LBOs and asserting that these gains are attributable to management's control position and their ability to obtain private benefits from material, non-public information). 
shareholder wealth. ${ }^{14}$ It was said management was seizing a "pot of gold" by transferring to themselves unpaid shareholder premium. ${ }^{15}$ Defenders of these transactions argued that they increased aggregate social wealth by, among other things, decreasing agency costs and properly incentivizing management. ${ }^{16}$ These gains were largely captured by shareholders. ${ }^{17}$ At the time, studies analyzing these divergent arguments came to conflicting conclusions. $^{18}$

The debate has continued with periodic studies continuing to arrive at alternative conclusions as to whether management involvement in the acquisition process can skew the results and the wealth effects of takeovers. ${ }^{19}$ But the level of judicial review of these transactions has remained

${ }^{14} I d$. at 22 .

${ }^{15}$ See ECON. DIV. CONG. RESEARCH SRV., 100TH CONG., LEVERAGED BUYOUTS AND THE Pot of Gold: Trends, Public Policy, AND CASE STUdies, 1-2, 46-52 (Comm. Print 1987) (assessing the benefits and detriments of LBOs with regards to general economic value, effect on shareholders, and the role of congressional oversight); see also Louis Lowenstein, Management Buyouts, 85 COLUM. L. REV. 730, 731 (1985) ("Transactions of such suspiciously little economic and social value require reappraisal."); Victor Brudney \& Marvin A. Chirelstein, A Restatement of Corporate Freezeouts, 87 YALE L.J. 1354, 1367 (1978) ("[G]oing private transactions should in all cases be prohibited.").

${ }^{16}$ See Joseph A. Grundfest, Management Buyouts and Leveraged Buyouts: Are the Critics Right?, in LEVERAGED MANAGEMENT BUYOUTS: CAUSES AND CONSEQUENCES 241, 242-43 (Yakov Amihud ed., 1989) ("[I]t makes sense . . to view buyouts . . a risky but beneficial opportunities for industrial rebirth at firms that may not be living up to their full potential. While there is extensive debate over the sources of gain that result from buyouts, the most significant gains result, I believe, from the reduction in agency costs that occurs when management is given an opportunity to share a substantial equity stake in the firm it operates."); Michael C. Jensen, LBOs and the Reemergence of Institutional Monitoring of Managers, in LEVERAGED MANAGEMENT BUYOUTS: CAUSES AND CONSEQUENCES 263, 265 ("[Management] who own or represent in the buyout funds an average of $60 \%$ of the firm's equity have great incentive to take the job seriously, in contrast to public directors with little or no equity interest.") (internal citation omitted); Richard A. Booth, Management Buyouts, Shareholder Welfare, and the Limits of Fiduciary Duty, 60 N.Y.U. L. REV. 630, 665 (1985) ("[B]ecause management buyouts have positive value for managers, shareholders, and the economy alike, they should be encouraged rather than discouraged."); Dale Arthur Oesterle \& Jon R. Norberg, Management Buyouts: Creating or Appropriating Shareholder Wealth?, 41 VAND. L. REV. 207, 224-228 (1988) (reviewing justifications for MBOs on agency cost-savings and tax efficiency grounds).

${ }^{17}$ See Sridhar Gogineni \& John Puthenpurackal, The Effects of Management Involvement on Takeover Competition and Shareholder Returns 31 (March 25, 2011) (unpublished manuscript), available at $\mathrm{http}: / / \mathrm{ss}$.com/abstract $=1572971$ (finding that shareholders obtain higher returns in management-involved deals).

${ }^{18}$ See infra Part II.C.

${ }^{19}$ Compare Kai Chen et al., Hands in the Cookie Jar? The Case of Management Buyouts 3 (2009), available at http://ssm.com/abstract=1364655 ("[T]ransaction premiums are negatively associated with the buyout managers' stock holdings, and positively associated with their option holdings.") (quoting abstract to article); with Gogineni \& Puthenpurackal, supra note 17, at 3-5 (examining a sample of going private transactions from 1995-2007 with target management involvement and finding comparable wealth effects to buy-outs without management involvement). 
unchanged, and these transactions are still generally reviewed under the ordinary state statutory conflict of interest transaction rules. ${ }^{20}$ This review is different than the heightened judicial review imposed on freeze-outs during the 1970 s and 1980 s in response to similar wealth appropriation claims. ${ }^{21}$ During this time and into the 1990s, the Delaware courts held that freezeouts were subject to both heightened procedural and judicial review for "entire faimess," a substantive standard which involves a court deciding after the transaction's completion whether "entire fairness" was achieved. ${ }^{22}$ This review has trended in recent years towards the use of procedural mechanisms rather than substantive ones, as Delaware particularly has relaxed its requirements for ex post facto court scrutiny through "entire fairness" review, and instead allowed freeze-out transactions to comply solely with $\mathrm{ex}$ ante procedural protections such as majority of minority conditions. ${ }^{23}$

The trend in freeze-out jurisprudence raises an important issue: Assuming the need for regulation of these transactions, what level of process is necessary to prevent agents from leveraging their positions to obtain private benefits in takeovers? More specifically, to what extent are these conflicts mitigated by procedures that defer to the parties to privately order their relationship ex ante, instead of by resolution through a judicial regime.

${ }^{20}$ See, e.g., infra Part III.C; James D. Cox, Managing and Monitoring Conflicts of Interest: Empowering the Outside Directors with Independent Counsel, 48 VILL. L. REV. 1077, 1077-81 (2003).

${ }^{21}$ For discussions of the issue during the 1970 s, see Victor Brudney, A Note on "Going Private", 61 VA. L. REV. 1019, 1021-26 (1975); see also Brudney \& Chirelstein, supra note 15, at 1354-56; Edward F. Greene, Corporate Freeze-out Mergers: A Proposed Analysis, 28 STAN. L. REV. 487, 496-500, 502-03 (1976). A freeze-out transaction is generally defined as an acquisition of the minority interest in a public company by a controlling shareholder. See id. at 489-90 \& n.8.

${ }^{22}$ See Kahn v. Lynch Commc'ns Sys., 638 A.2d 1110, 1115 (Del. 1994); Weinberger v. UOP, Inc., 457 A.2d 701, 710-11 (Del. 1983).

${ }^{23}$ See Glassman v. Unocal Exploration Corp., 777 A.2d 242, 247-48 (Del. 2001) (holding that a short-form squeeze out merger with a controlling shareholder was not subject to "entire fairness" review absent fraud or illegality); In re CNX Gas Corp. S'holders Litig., 4 A.3d 397, 41213 (Del. Ch. 2010) (holding that a going private transaction via tender offer required approval by a special committee of independent directors to qualify for review under the business judgment rule); In re Pure Res. S'holders Litig., 808 A.2d 421, 445 (Del. Ch. 2002) (setting forth a tripartite procedural standard requiring a majority of minority condition and formation of a special committee of independent directors to qualify for business judgment review under the Siliconix holding); In re Siliconix Inc. S'holders Litig., 2001 WL 716787, at *6- 8 (Del. Ch. June 19, 2001), reprinted in 27 DEL. J. CORP. L. 1011, 1021-25 (2002) (holding that a non-coercive tender offer by a controlling shareholder was subject to review under the business judgment rule rather than "entire faimess"). For a discussion of Delaware's judicial shift in this direction, see Peter V. Letsou \& Steven M. Haas, The Dilemma That Should Never Have Been: Minority Freeze Outs in Delaware, 61 BUS. LAW. 25, 26-27 (2005). See generally Guhan Subramanian, Fixing Freezeouts, 115 YALE L. J. 2, 17-21 (2005) (examining Delaware case law on going-private transactions and the history of judicial review thereof). 
If procedure is the preferred protective mechanism, what procedures, contractual and otherwise, actually provide value? These questions are particularly ripe with respect to $\mathrm{MBO}$, which are not automatically subject to the higher substantive and procedural requirements applied to freeze-outs, and therefore are structured more heterogeneously.

In order to more fully examine the latter question, we compiled a dataset of MBOs announced from 2003 through 2009 . We then empirically studied the contract terms and processes associated with these transactions. In addition, we compiled from court records an extensive set of litigation rates and outcomes in order to measure the effect of litigation on MBO outcomes. We have thus measured the value of "process" through board procedures, contractual mechanisms, and litigation in conflicted interest transactions involving MBOs.

We find that process, including board procedures and contractual terms, does matter in MBOs. In particular, we find that the existence of a special committee is associated with higher offer premiums. Contracts we deem to be "competitive" (i.e., providing for contractual protection of unaffiliated shareholders) also result in higher premiums than noncompetitive contracts. MBOs initiated by management as opposed to the board or an outside party are associated with lower bidding premiums. ${ }^{24}$ This provides evidence for the theory that management times and affects the MBO process to its private benefit, though it does not answer the question about the social utility of these transactions. Our results are robust to inclusion of industry controls, time effects, various contract terms, and process variables.

In the subsample of transactions announcing an above-median initial offer premium, we find that the competitiveness of the contracting process is unrelated to transaction completion rates. This intuitive result highlights the fact that economic forces are more important determinants of bidding outcomes when the MBO process begins with an economically appealing offer to target shareholders. In contrast, MBOs starting out with belowmedian offer premiums are more subject to lawsuits and attempts by shareholders to defeat or renegotiate offers. We find that in this subset of transactions contract competitiveness matters significantly: More competitive contracts are associated with greater bid failure rates, consistent with the idea that the contracting process matters and provides voice to

\footnotetext{
${ }^{24} \mathrm{We}$ anecdotally discuss this point further in the context of the recent controversial J.Crew MBO infra at notes 202-05 and accompanying text.
} 
shareholder concerns. Target shareholders benefit from more competitive contracts when faced with potentially coercive going-private offers.

We believe this is the first complete study of the role of process in MBOs. Our results show that process indeed matters in MBOs, and that certain mechanisms which empower shareholders in the decision process appear to particularly matter. In addition, we find that MBO merger transactions with controlling shareholders, which are also subject to "entire fairness" review, do not result in higher offer premiums. Our results provide support for the Delaware courts' adoption of procedural protections in takeovers where management principal/shareholder agency conflict exists. Our findings also inform the appropriate judicial standard for review of MBOs and any necessary substantive parameters.

Part I of this Study details the emergence of the $\mathrm{MBO}$ and its history. Part II discusses the theoretical arguments for and against MBOs as well as the prior literature on the subject. Part III discusses the role and value of process in takeovers and its use in conflicted transactions, particularly MBOs. Part IV sets forth a description of our data collection process and resulting dataset and describes the results of our statistical and econometric analysis. Part V concludes with recommendations for policy and normative practices in MBOs.

\section{THE EMERGENCE OF THE MBO}

MBOs became a prominent fixture on the takeover landscape during the 1980 s due primarily to the increased viability of the leveraged buy-out ("LBO"). ${ }^{25}$ In its most basic form the LBO involves a private equity firm, or other acquirer, borrowing approximately 60 to $90 \%$ of the transaction value to acquire a company's outstanding equity. ${ }^{26}$ During the $1980 \mathrm{~s}$, LBOs constituted approximately $24.5 \%$ of all takeovers. ${ }^{27}$ The LBO's rise during this time was attributable to a number of factors, including a deregulated

\footnotetext{
${ }^{25}$ See Steven N. Kaplan, The Effects of Management Buyouts on Operating Performance and Value, 24 J. FIN. ECON. 217, 217 (1989).

${ }^{26}$ See Bengt Holmstrom \& Steven N. Kaplan, Corporate Governance and Merger Activity in the United States: Making Sense of the 1980s and 1990s, J. ECON. PERSP., Spring 2001, at 121, 121. But see Matthew D. Cain, Steven M. Davidoff \& Antonio J. Macias, Broken Promises: Private Equity Bidding Behavior and the Value of Reputation 14-15 (Aug. 24 2011) (Working Paper) available at http://papers.ssrn.com/sol3/papers.cfm?abstract_id $=1540000$ (noting that many recent buyouts have been financed entirely with equity).

${ }^{27}$ Source: Thomson Reuters data compilation covering completed acquisitions of public U.S. targets. LBOs constituted $12.6 \%$ of all public takeovers on an equal-weighted basis, and $24.5 \%$ of all public takeovers on a transaction value-weighted basis.
} 
takeover market and Michael Milken's creation of a high-yield debt market, which allowed for the financing of LBOs in greater number and size. ${ }^{28}$

The appearance of MBOs was similarly attributed to the increased availability of debt and a more active takeover market. ${ }^{29}$ Management, either alone or with another acquisition group, would acquire a company under their control by arranging debt financing in leverage ranges equivalent to an $\mathrm{LBO}^{30}$ Due to this leverage and need for debt financing, MBOs were often structured similar to LBOs."

The impact of the MBO on the public and popular imagination was greater than its frequency. Proposed MBOs for RJR/Nabisco and MacMillan \& Co. were subject to harsh media and judicial scrutiny. ${ }^{32}$ In both cases, management was portrayed in the press as greedy agents seeking to obtain private benefits at the expense of shareholders. ${ }^{33}$ The view that management was obtaining undue amounts of wealth was affirmed in public opinion as particularly lucrative MBOs emerged. ${ }^{34}$ One such example was the Gibson Greetings MBO. In 1982, the management of Gibson Greetings Inc., a subsidiary of the conglomerate RCA Corp., arranged an MBO of their own company for $\$ 80$ million. ${ }^{35}$ The overwhelming portion of this was financed by $\$ 79$ million in debt. ${ }^{36}$ Only eighteen months later the company went public, selling itself at a price that valued the company at more than

${ }^{28}$ See GLENN YAGO, JUNK BONDS: HOW HIGH YIELD SECURITIES RESTRUCTURED CORPORATE AMERICA 20, 21, 23, 25, 30 (1991) (detailing the history of Milken's and Drexel Burnham's creation of the high-yield bond market). This active takeover market was itself a product of a number of factors that are still the subject of debate, but likely included the deregulatory antitrust and economic policies of the Reagan administration as well as the Supreme Court's move to strike down state anti-takeover laws in CTS Corp. v. Dynamics Corp. of America, 481 U.S. 69 (1989). See Holmstrom \& Kaplan, supra note 26, at 122, 125.

${ }^{29}$ See Luc Renneboog \& Tomas Simons, Public-to-Private Transactions: LBOs, MBOs, $M B I$, and IBOs 3-4 (Eur. Corp. Governance Inst., Finance Working Paper No. 94/2005, 2005), available at $\mathrm{http}: / / \mathrm{ssm}$.com/abstract_id=796047.

${ }^{30}$ See Yakov Amihud, Leveraged Management Buyouts and Shareholders' Wealth, in LEVERAGED MANAGEMENT BUYOUTS: CAUSES AND CONSEQUENCES, supra note 16, at 3, 3-4.

${ }^{31}$ See id; see also Kaplan, supra note 25, at 222-23, 223 tbl.2 (examining the size, premiums, and leverage characteristics in a sample of MBOs).

${ }^{32}$ See BRYAN BURROUGH \& JOHN HELYAR, BARBARIANS AT THE GATE: THE FALL OF RJR NABISCO 310, 341, 354 (1990); see also Grundfest, supra note 16, at $257 \mathrm{n} .22$ (asserting that the battle for control of MacMillan "well illustrated" a board's failure to maintain adequate independence from management proposing an $\mathrm{MBO}$ ).

${ }^{33}$ See BURROUGH \& HELYAR, supra note 32, at 341; Cynthia Crossen \& Karen Blumenthal, An Anti-Takeover Arsenal that Failed-Macmillan Tried Many Defenses to Stop Suitors, WALLST. J., Nov. 4, 1988, at 1.

${ }^{34}$ See Stein, supra note 13, at 6; Benjamin J. Stein, A Saga of Shareholder Neglect: Whose Interest Was This Management Protecting?, BARRON's, May 4, 1987, at 72-73, 75.

${ }^{35}$ BURROUGH \& HELYAR, supra note 32 , at 140.

${ }^{36} I d$. 
$\$ 290$ million. ${ }^{37}$ Conversely, the 1988 bankruptcy of Revco D.S., Inc., only nineteen months after its $\mathrm{MBO}$, anecdotally affirmed in the public mind the risky nature of these transactions, and led to outcries that LBOs generally destroyed wealth. ${ }^{38}$ While this was the popular image of MBOs, the truth was less certain.

The controversy over management involvement during this time led to calls for heightened regulation of MBOs. ${ }^{39}$ Louis Lowenstein called for an open bidding regime prior to a management takeover. ${ }^{40}$ Victor Brudney called for banning these transactions altogether. ${ }^{41}$ Other commentators called for varying levels of increased judicial scrutiny of MBOs. ${ }^{42}$ These calls were countered by those who argued that MBOs were simply part of an efficient capital market, and that heightened regulation would diminish MBO rates and prevent wealth-increasing transactions. ${ }^{43}$ Despite the fomentation, no significant regulation particular to MBOs was adopted during this time. ${ }^{44}$ The only major proposal was one by the American Law Institute ("ALI") to mandate an open bidding regime similar to the one advocated by Professor Lowenstein. $^{45}$ It was never adopted by the ALI, or by any state.

The debate over MBOs and their regulation faded away in the 1990s as these transactions diminished in number due to the failure of the high yield debt market in 1989, and the subsequent general decline in the credit and LBO markets. ${ }^{46}$ These transactions, however, experienced resurgence in $1999 .{ }^{47}$ From 1999 to 2003, MBOs constituted one to three percent of the domestic public takeover market. ${ }^{48}$ This upward swing continued in the

${ }^{37}$ Id.; see also Gary Hector, Are Shareholders Cheated by LBOs?, FORTUNE, Jan. 19, 1987, at 98, 99 (detailing John Kluge's 1984 MBO of Metromedia and his personal profit of approximately $\$ 3$ billion).

${ }^{38}$ See ROBERT F. BRUNER, DEALS FROM HELL: M\&A LESSONS THAT RISE ABOVE THE ASHES 133 (2005).

${ }^{39}$ Ronald J. Gilson, Market Review of Interested Transactions: The American Law Institute Proposal on Management Buyouts, in LEVERAGED MANAGEMENT BUYOUTS: CAUSES AND CONSEQUENCES, supra note 16, at 217, 220, 222.

${ }^{40}$ Lowenstein, supra note 15 , at $731-32$.

${ }^{41}$ Brudney \& Chirelstein, supra note 15 , at 1367.

${ }^{42}$ See, e.g., Oesterle \& Norberg, supra note 16, at 252-53, 255 (arguing that the courts should subject MBOs to stricter scrutiny with respect to the role of the independent committees and disclosure).

${ }^{43}$ See, e.g., Grundfest, supra note 16, at 243-44; Booth, supra note 16, at 646-47.

${ }^{44}$ See, e.g., Edward J. Markey, Legislative Views on Management Bryouts, in LEVERAGED MANAGEMENT BUYOUTS: CAUSES AND CONSEQUENCES, supra note 16, at 211, 211.

${ }^{45}$ See Gilson, supra note 39, at 223.

${ }^{46}$ See Renneboog \& Simons, supra note 29 , at 4.

${ }^{47}$ See id.

${ }^{48}$ Source: Thomson Reuters. These figures are as recorded by Thomson Reuters, but as discussed infra Part IV.A, Thomson Reuters statistics are not comprehensive, and are subject to 
period from 2003 through 2009 . The following chart sets forth the number and aggregate enterprise value of MBOs announced during this time period:

Chart A. MBO Trends, 2003-2009

Number of MBO transactions for each semiannual period from 2003 to 2009. Aggregate enterprise values in nominal billions of U.S. dollars.

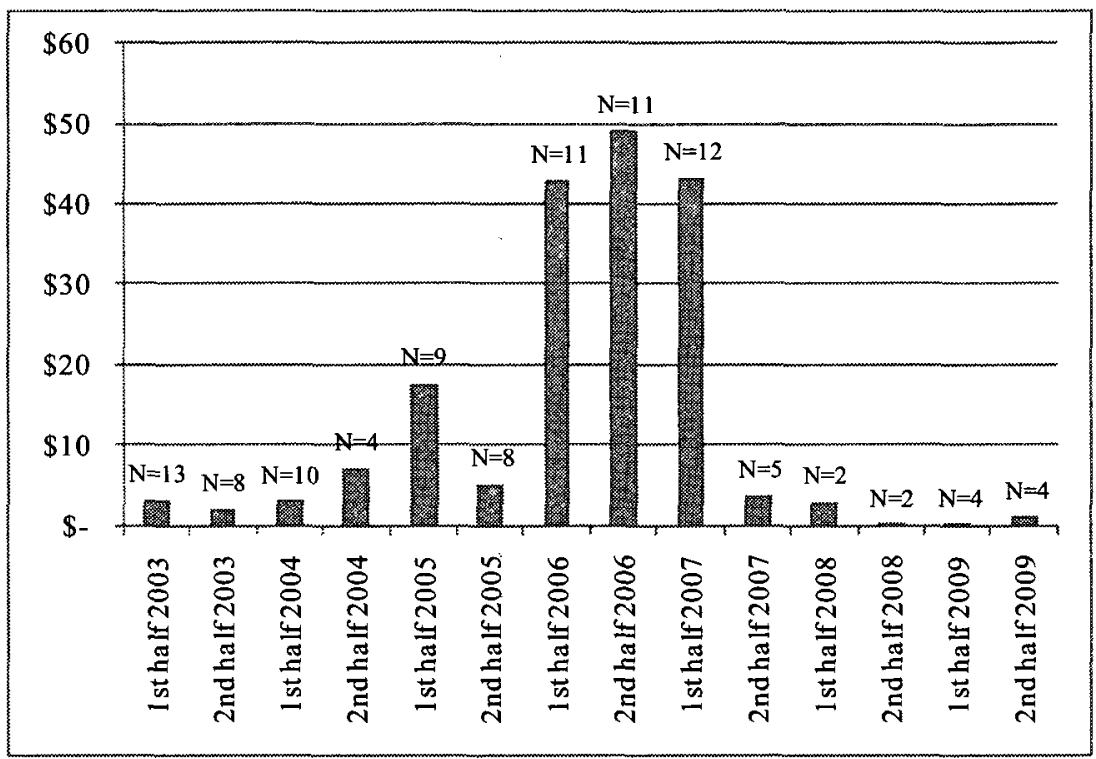

The form and structure of MBOs changed in the new millennium. Management became less likely to be the primary equity capital provider or organizing force in these transactions. ${ }^{49}$ Instead, a private equity firm would initiate discussions to acquire the company in partnership with management. ${ }^{50}$ As part of the acquisition, management would cash out a portion of their equity interests, but also receive an ownership interest and employment agreements with the newly private company. ${ }^{51}$ Technically,

coding choices. See also Renneboog \& Simons, supra note 29, at 4 (detailing trends in the MBO and LBO markets in the late 1990 s and early 2000 s).

${ }^{49}$ See Brian Cheffins \& John Armour, The Eclipse of Private Equity, 33 DEL. J. CORP. L. 1, 9 (2008)

${ }^{50}$ See id. at $9,12-13$.

${ }^{51}$ See id. at 12-13. 
these were management buy-ins ("MBIs"), not MBOs, ${ }^{52}$ and they allowed management to profit while simultaneously diversifying their portfolio and reducing their investment risk profile. ${ }^{53}$

The structure of these deals also evolved. A new mechanism called the "go-shop" was introduced. ${ }^{54}$ Included in acquisition agreements, the goshop provision provided that a target could conduct a post-announcement market-check for a pre-specified period of time, typically twenty to sixty days. ${ }^{55}$ During this time period, the target, its investment bankers, and other target representatives were free to contact third party bidders and provide them with non-public information concerning the company. ${ }^{56}$ This purportedly permitted a full "shopping" of a target when it had preannouncement negotiations with only one or two potential acquirers. ${ }^{57}$

Go-shop provisions became widely utilized beginning in 2003 , and were primarily used in private equity and MBO transactions. ${ }^{58}$ A number of commentators claimed that these devices were merely cosmetic, designed to paper over the head start the initial acquirer obtained and the position it established through pre-announcement negotiation of a lock-up agreement..$^{59}$ The use of lock-ups was particularly significant in private equity buy-outs with management participation, since private equity firms have been accused of unwillingness to counter-bid against fellow firms. At least one study examining this issue confirmed that this was true. ${ }^{60}$ A related study of go-

\footnotetext{
${ }^{52}$ Throughout this study, we refer to both MBO and MBI transactions collectively as "MBOs." However, there is no agreed classification to differentiate these transactions. In Part V we offer refined definitions of both types of transactions based on our findings.

${ }^{53}$ See Renneboog \& Simons, supra note 29, at 3.

${ }^{54}$ See Christina M. Sautter, Shopping During Extended Store Hours: From No Shops to GoShops: The Development, Effectiveness, and Implications of Go-Shop Provisions in Change of Control Transactions, 73 BROOK. L. REV. 525, 529 (2008).

${ }^{55}$ See id.

${ }^{56}$ See id. at $529-30$.

${ }^{57}$ See id.

${ }^{58}$ See Mark A. Morton \& Roxanne L. Houtman, Go-Shops: Market Check Magic or Mirage?, POTTER ANDERSON \& CORROON, 5 (Feb. 2008), http://www.potteranderson.com/assets/ attachments/Go-ShopsRevFeb2008.pdf.

${ }^{59} I d$. at 7, 9. But see Guhan Subramanian, Go-Shops vs. No-Shops in Private Equity Deals: Evidence and Implications, 63 BUS. LAW. 729, 730 (2008) (examining a sample of private equity transaction from January 2006 through August 2007 and finding that in "pure" go-shops, where the seller negotiates exclusively with one buyer pre-transaction announcement, in comparison to "addon" go-shops, yield approximately 5\% higher returns to target shareholders).

${ }^{60}$ See Micah S. Officer et al., Club Deals in Leveraged Buyouts, 98 J. FIN. ECON. 214, 21415 ("[T] ]arget shareholders in club deals receive significantly lower premiums than in sole-sponsored LBOs and other merger and acquisition transactions.... [T] arget shareholders receive approximately $10 \%$ less of pre-bid firm equity value, or roughly $40 \%$ lower premiums, in club deals compared to sole-sponsored LBOs."); see also Audra L. Boone \& J. Harold Mulherin, Do Private Equity Consortiums Facilitate Collusion in Takeover Bidding? 5, 8 (Dec. 2010) (unpublished
} 
shops also found them of limited value when management was involved in the bidding consortium. ${ }^{61}$

The rise of more complex and complete capital markets made financing the $\mathrm{MBO}$ easier and allowed for the provision of greater value to shareholders. ${ }^{62}$ The emergence of activist hedge funds and proxy advisory services in the new millennium provided a greater potential check on management behavior. ${ }^{63}$ These entities could actively solicit shareholders to oppose a transaction that did not maximize shareholder wealth. ${ }^{64}$ However, this check itself seldom appeared in MBO transactions. We find that from 2003 to 2009 only $1.9 \%$ of these transactions were rejected by shareholder votes. Still, the threat of this action may have disciplined directors considering these transactions and produced higher premiums and shareholder contractual protections.

The emergence of more complete capital markets, due to advances in financial engineering and the creation of more complex derivative products, allowed for management to better align risk and capital. ${ }^{65}$ Debt could be issued in greater amounts and with more specificity, and assets could be securitized to both raise capital and allocate risk. ${ }^{66}$ The result was the potential for more debt financing capacity for MBOs and for the creation of greater levered return on equity - wealth which could be bargained over by, and allocated between, shareholders and management. ${ }^{67}$ This was readily apparent in the increase in MBI transactions from 2004 to 2007, though this was in part due to the credit bubble that preceded the financial crisis and provided cheap financing for these transactions. ${ }^{68}$

manuscript) available at http://ssm.com/abstract=1 104224 (studying a sample of 870 takeovers of publicly traded targets from 2003 to 2007 and finding that private equity bidders and private equity consortiums are associated with higher rates of competition).

${ }^{61}$ See Subramanian, supra note 59, at 731 ("Non-MBOs with a pure go-shop clause are jumped $23 \%$ of the time, while MBO go-shops are never jumped.").

${ }^{62}$ See Ronald J. Gilson \& Charles K. Whitehead, Deconstructing Equity: Public Ownership, Agency Costs, and Complete Capital Markets, 108 COLUM. L. REV. 231, 235, 251-53 (2008).

${ }^{63}$ For a discussion of the rise of the hedge fund activist investor and its effects, see Alon Brav et al., Hedge Fund Activism, Corporate Governance, and Firm Performance, 63 J. FiN. 1729, 1729-36 (2008). See also Marcel Kahan \& Edward B. Rock, Hedge Funds in Corporate Governance and Corporate Control, 155 U. PA. L. REV. 1021, $1021-45$ (2007) (discussing activist hedge funds and their influence on corporate management and business strategy).

${ }^{64}$ See Alon Brav et al., supra note 63, at 1729, 1729-33; Kahan \& Rock, supra note 63, at $1021,1021-45$.

${ }^{65}$ See Gilson \& Whitehead, supra note 62, at 231, 235, 251-53.

${ }^{66}$ See id. at 245-47.

${ }^{67}$ Ulf Axelson, et al., Why are buyouts levered? The Financial Structure of Private Equity Funds, 64 J. FIN. 1549, 1570-72 (2009).

${ }^{68}$ See Cheffins \& Armour, supra note 49 , at 22-25. 
Even after the financial crisis, the MBO has continued to be a fixture of the takeover scene. The downturn in shareholder prices has again caused observers and market participants to accuse management of attempting to time the buyout process while stock prices are diminished to obtain control of the corporation. ${ }^{69}$ The Bankrate transaction is one such example. ${ }^{70}$ Furthermore, with the decline of financing capacity for larger private equity deals, private equity firms have focused on smaller companies, producing a higher number of transactions with management participation in proportion to the overall takeover market."

\section{THE UNDERPINNINGS OF MBOS}

The return of the MBO and the early public scrutiny of these transactions belied a more fundamental debate about the efficacy of management participation in buy-outs. These objections largely center around differing and over-lapping arguments based on fairness and economic grounds. The validity of these theories was challenged by many, and studies, mostly from the 1980 s, came to differing conclusions as to the effect of these transactions on shareholder wealth and their driving forces. The result is that even today there is uncertainty over the reasons for, and economic utility and effects of these transactions.

\section{A. Theoretical Objections to $M B O S$}

A principal objection to an MBO transaction is that it breaches a species of the public trust doctrine. This doctrine is today most often cited as a land use principle; but it traces its conception to democratic notions of public trust in government and the faith the public consequently puts in its representative officials. ${ }^{2}$ In the MBO context, the doctrine can be applied as follows: Managers as agents are entrusted by public shareholders with the task of operating and monitoring the corporate enterprise. When management profits at the expense of shareholders through an MBO it violates a public trust. More particularly, such actions dilute public faith and

\footnotetext{
${ }^{69}$ See, e.g., Andrew Ross Sorkin, Rewriting the Rules for Buyouts, N.Y. TIMES, Nov, 19, 2006, at 3 ("Every day, it seems, some stock that has been battered is being picked off by its own management .... It's hard to understand how shareholders can trust management to represent their interests when it is trying to make off with the company.").

${ }^{70}$ See Davidoff, supra note 6.

${ }^{71}$ Source: Thomson Reuters.

${ }^{72}$ See George P. Smith II \& Michael W. Sweeney, The Public Trust Doctrine and Natural Law: Emanations Within A Penumbra, 33 B.C. ENVTL. AFF. L. REV. 307, 310-14 (2006).
} 
reliance in the capital markets. Economically this can result in less demand for public securities, lower aggregate pricing of securities, and an increased cost of capital for companies as the public seeks ex ante compensation for a perceived prospective, inappropriate wealth transfer through a potential MBO.

Distinct from this economic rationale, though, is an "integrity of the markets" argument undergirding the public trust doctrine. If management could operate the company for a profit themselves, why should this profit not go to the shareholders? After all, management has been hired and placed in this position as agents for shareholders. Any profit they derive is therefore owed to the shareholders. The integrity of the markets requires that manager agents place their fiduciary duty above their own economic interest. ${ }^{73}$

There is a more concrete argument against MBOs on fairness grounds. It is the prospect that management is utilizing inside information when it arranges an MBO. Management by its inherent position has in its possession non-public knowledge of the corporation, and management can use this informational asymmetry between itself and public shareholders to time the buy-out process. ${ }^{74} \mathrm{MBO}$ can thus be arranged at advantageous times in the business cycle or history of the corporation. ${ }^{75}$ Management can further manipulate this process through its control of the proxy machinery and ability to under-disclose information or otherwise manipulate company projections or even company earnings and revenues leading up to the transaction. ${ }^{76}$ This view has been buttressed by studies that find MBO firms

\footnotetext{
${ }^{73}$ This argument was most prominently addressed in 1974 in a polemical speech by SEC Commissioner A.A. Sommer, in which he attacked MBOs and going-privates. See A. A. Sommer, Jr., Comm'r, Sec. \& Exch. Comm'n, Law Advisory Council Lecture at Notre Dame Law School: "Going private": A Lesson in Corporate Responsibility, 3, 11-12 (Nov. 14, 1974), available at http:/www.sec.gov/news/speech/1974/111474sommer.pdf.

${ }^{74}$ See Roberta Romano, Management Buyout Puzzles, in LeVERaged MaNagement BUYOUTS: CAUSES AND CONSEQUENCES, supra note 16, at 199, 204 \& n.7 (asserting that use of insider information by management in an MBO would comprise a breach of fiduciary duty to public shareholders). Other studies note the potential for management to create shareholder wealth through market-timing of capital structure decisions. See, e.g., Malcolm Baker \& Jeffrey A. Wurgler, Market Timing and Capital Structure, 57 J. FIN. 1, 1-2, 25, 27 (2002) (finding that the way companies structure corporate financing is consistent with the "market timing" theory of capital structure).

${ }^{75}$ See Roberta Romano, Management Buyout Puzzles, in LEVERAGED MANAGEMENT BUYOUTS: CAUSES AND CONSEQUENCES, supra note 16, at 199, 204 ("[M]anagers who take the firm private and later take it public again $\mathrm{kn}[\mathrm{ow}]$ something about the firm's future projections that was not, and perhaps could not be, disclosed in the market at the time of the buyout."). Contra Kaplan, supra note 25, at 249 (disputing informational asymmetry "market timing" assertion by finding that management often relied on overly rosy projections in implementing buy-outs).

${ }^{76}$ See Linda Elizabeth DeAngelo, Accounting Numbers as Market Valuation Substitutes: $A$ Study of Management Buyouts of Public Stockholders, 61 ACCT. REV. 400, 401, 417-18 (1986)
} 
are different than other public targets and possibly more prone to such manipulation. For example, Maupin, Bidwell and Ortegren find that MBO firms are significantly different in terms of concentration of stock ownership, cash flow ratios, and dividend yield than other publicly related targets. ${ }^{77}$

The position of management as agent for the shareholders provides them with additional ability to manipulate the corporate process to arrange an MBO and another objection to MBOs. Directors, who are often appointed with management influence, can be swayed to otherwise approve conflicted interest transactions. ${ }^{78}$ Managers often sua sponte propose these transactions to directors. The board is then faced with the decision of catering to management or rejecting the proposal and possibly having to replace the entire management team. ${ }^{79}$ Faced with this difficult decision, directors decide to take the easier course and sell the company. ${ }^{80}$ Meanwhile, open bidding does not occur due to management's ability to negotiate protective lock-ups in acquisition contracts. ${ }^{81}$ During the private equity boom of 2004 to 2007, there came new charges that management, aware its ability to obtain both protective lock-up provisions and director approval, would often steer the acquisition process away from strategic buyers and towards a private equity firm that would provide an MBI opportunity to management. ${ }^{82}$ This accusation was supported by antitrust claims and studies which found that private equity firm consortiums were loath to trump

(recognizing that managers have strong incentives to finesse earnings before executing management buyouts, but finding no evidence of such action in collection of firms studied).

${ }^{77}$ Rebekah J. Maupin, et al., An Empirical Investigation of the Characteristics of PubliclyQuoted Corporations Which Change to Closely-Held Ownership Through Management Buyouts, 11 J. BUS. FIN. \& ACCT. 435, 441-42 (1984); see also Michael C. Jensen, Takeovers: Their Causes and Consequences, J. ECON. PERSP., Winter 1988, at 21, 31 ("Many of the benefits in going-private and leveraged buyout transactions seem to be due to the control function of debt."); Michael C. Jensen, Agency Costs of Free Cash Flow, Corporate Finance, and Takeovers, 76 AM. ECON. REV. 323,325 (1986) (asserting that the economic rationale for an LBO is "substantial free cash flow" to support sufficient, necessary debt).

${ }^{78}$ This pressure can be generated internally as well as in response to a more general, external threat of a change of corporate control. See Andrei Shleifer \& Robert W. Vishny, Management Buyouts as a Response to Market Pressure, in MERGERS AND ACQUISITIONS 87, 89-92 (Alan J. Auerbach ed., 1988).

${ }^{79}$ See Stephen M. Bainbridge, Unocal at 20: Director Primacy in Corporate Takeovers, 31 DEL. J. CORP. L. 769, 819-21 (2006).

${ }^{80}$ See id.

${ }^{81}$ John C. Coates IV, An Empirical Reassessment of MBO Bids: Techniques, Outcomes and Delaware Corporate Law 12 (Oct. 18, 2005) (unpublished manuscript), available at http://www.law.columbia.edu/center_program/law_economics/wkshops/2005_FallTerm. For a definition of lock-ups, see infra notes 180-82 and accompanying text.

${ }^{82} \mathrm{~A}$ judicial example of this occurred in the case of In re Netsmart Techs., Inc. S'holders Litig., 924 A.2d 171, 175 (Del. Ch. 2007). The CEO of the target company in that instance deliberately arranged an auction process to exclude non-private equity bidders. $I d$. 
bids of other private equity firms, resulting in a diminished market for corporate control. ${ }^{83}$

Objections to MBOs not only focus on shareholders but also other corporate constituents, particularly employees and bondholders. The objections concerning the ability of managers to extract wealth benefits from employees and bondholders are similar to those raised concerning traditional LBOs. In the case of employees, management can be claimed to be expropriating wealth by arranging for employee cut-backs and other expenditure reductions management was otherwise unwilling to make when the company was public. ${ }^{84}$ This can further extend to an under-investment in capital resources in order to service the additional debt acquired in an MBO. ${ }^{85}$

In the case of bondholders, bond indentures in the early 1980 s did not contain extensive event risk covenants. ${ }^{86}$ This permitted management and other acquirers to easily transfer wealth from bondholders to management in an $\mathrm{LBO}$ or $\mathrm{MBO}{ }^{87}$ The most singular instance of this was the 1989 RJR/Nabisco LBO. ${ }^{88}$ The private equity group KKR acquired RJR/Nabisco and placed a significant amount of increased leverage on the company with debt secured at a level above prior debt holders. ${ }^{89}$ The result was a severe

${ }^{83}$ See supra notes 59-60 and accompanying text. Notably this argument is not relevant when the MBO is made as a competing bid. See ALLEN MICHEL \& ISRAEL SHAKED, TAKEOVER MADNESS: CORPORATE AMERICA FIGHTS BACK 126-27 (1986).

${ }^{84}$ For a more general discussion of this issue in the context of LBOs, see Steven J. Davis et al., Private Equity and Employment 9 (U.S. Census Bureau Ctr. for Econ. Studies, Working Paper No. CES 08-07, 2008), available at http://papers.ssm.com/sol3/papers.cfm?abstract id=1107175.

${ }^{85}$ Studies of this phenomenon have largely unfolded in the LBO context and generally found mixed results trending against this hypothesis. See Frank R. Lichtenberg \& Donald Siegel, The Effects of Leveraged Buyouts on Productivity and Related Aspects of Firm Behavior, 27 J. FIN. ECON. 165, 187-90 (1990) (analyzing National Science Foundation/Census Bureau's annual survey of industrial research and development investment for over 1,200 firms and finding decreases in relative $R \& D$ intensity for firms involved in LBOs, but noting that LBO targets tend not to be R\&D intensive and may have been decreasing in intensity before the buyout); Robert J. Shapiro and Nam D. Pham, The Impact of Private Equity Acquisitions and Operations on Capital Spending, Sales, Productivity, and Employment, PRIVATE EQUITY GROWTH CAP. COUNCIL 1, 6-8 (Jan. 2009), http://www.pegcc.org/wordpress/wp-content/uploads/pec_economic-impact-study-01-23-09-

final.pdf ("Our analysis of capital expenditures by large companies acquired by major private equity firms during the period from 2002 through 2005 finds that their capital spending both accelerated after their acquisitions and grew five to 12 times faster than the averages for all U.S. businesses....").

${ }^{86}$ See Marcel Kahan \& Michael Klausner, Standardization and Innovation in Corporate Contracting (or "The Economics of Boilerplate"), 83 VA. L. REV. 713, 717, 746 (1997).

${ }^{87}$ Joseph A. Fields et al., Coupon Resets Versus Poison Puts: The Valuation of Event Risk Provisions in Corporate Debt, 3 FIN. SERV. REV. 143, 145, 148 (1994).

${ }^{88}$ Deborah A. DeMott, Introduction-The Biggest Deal Ever, 1989 DUKE L.J. 1, 1 (1989).

${ }^{89}$ See BURROUGH \& HELYAR, supra note 32, at 506. 
decline in the value of the pre-existing debt. ${ }^{90}$ After the RJR/Nabisco transaction, this risk was significantly eliminated since bond indentures began to include event risk covenants. ${ }^{91}$ Still, the securitization process prior to the financial crisis allowed for debt risk to be shifted from monitoring investment banks to security holders who may not have been appropriately incentivized or able to monitor these investments effectively. ${ }^{92}$ The tax benefit sustained by increasing the leverage of the corporation is the focus of a final set of objections to MBOs. Debt is tax deductible while equity is not. ${ }^{93}$ Under a Modigliani-Miller capital structure theorem, debt tends to increase the value of the corporate enterprise. ${ }^{94}$ By increasing a company's debt, an MBO creates wealth that could be allocated to managers. ${ }^{95}$ Thus, MBOs are simply a consequence of an unwarranted regulatory subsidy to management. ${ }^{96}$ Management is not creating wealth but merely conducting a regulatory arbitrage transaction subsidized by the federal government. ${ }^{97}$

\section{B. Theoretical Justifications for MBOs}

The counter-argument to the above objections is that MBOs are a net social good, creating wealth rather than reallocating it. The pillar of this argument is that these transactions reduce agency costs. ${ }^{98}$ An MBO eliminates the costs of compliance with public company regulation. ${ }^{99}$ More importantly, the increased debt load, the greater alignment of ownership and control, and the ability of management to earn superior returns, incentivize

\footnotetext{
${ }^{90}$ Fields et al., supra note 87 , at 148 .

${ }^{91}$ See generally Sung C. Bae et al., Event Risk Bond Covenants, Agency Costs of Debt and Equity, and Stockholder Wealth, 23 FIN. MGMT. 28, 28-29 (1994) (examining the effects of this event); Fields et al., supra note 87, at 143-44, 148.

${ }_{92}$ See Douglas O. Cook et al., Bondholder Wealth Effects of Management Buyouts, 21 FIN. MGMT. 102, 112 (1992) ("[S]ignificant bondholder wealth losses of about three percent [are] associated with the announcement of MBOs."); Arthur Warga \& Ivo Welch, Bondholder Losses in Leveraged Buyouts, 6 REV. FIN. STUD. 959, 962 (1993) ("[W]e find that nonconvertible bondholders experience significant wealth losses in LBOs."). But see Laurentius Marais et al., Wealth Effects of Going Private for Senior Securities, 23 J. FIN. ECON. 155, 155, 186-87 (1989).

${ }_{93}^{93}$ See I.R.C. $\$ 163($ a) (2010).

${ }^{94}$ Franco Modigliani \& Merton H. Miller, The Cost of Capital, Corporation Finance and the Theory of Investment, 48 AM. ECON. REV. 261, 264, 284 (1958).

${ }^{95}$ See id. at $264,284$.

${ }^{96}$ See Lowenstein, supra note 15 , at 762-63.

${ }^{97}$ Id.

${ }^{98}$ Richard Harris et al., Assessing the Impact of Management Buyouts on Economic Efficiency: Plant-Level Evidence from the United Kingdom, 87 REV. ECON. STAT. 148, 153 (2005).

${ }^{99}$ Robert L. Kieschnick, Jr., Management Buyouts of Public Corporations: An Analysis of Prior Characteristics, in LEVERAGED MANAGEMENT BUYOUTS: CAUSES AND CONSEQUENCES, supra note 16 , at 35,37 .
} 
management to operate the company more efficiently. ${ }^{100}$ These factors produce the operational and managerial efficiencies which create the gains that drive MBOs. ${ }^{101}$ Thus, the MBO transaction more efficiently allocates resources, and is wealth-creating. ${ }^{102}$

In the 1980s, some in the Chicago law and economics school argued that the debate over these transactions was immaterial. ${ }^{103}$ The existence of any takeover premium was a net gain to shareholders, ${ }^{104}$ and any loss to shareholders was simply lost surplus. ${ }^{105}$ Accordingly, wealth effects were created in any takeover, and the law and economic jurisprudence had nothing more to add. ${ }^{106}$ While an important argument in the $1980 \mathrm{~s}$, this argument has faded away against claims that there is value and a property right in the firm's cash flows generally, and a takeover premium more specifically, which should be allocated to shareholders. ${ }^{107}$ This counterargument is buttressed in the MBO context by the fact that the inside information management uses in the transaction is legally the property of the corporation and all of its shareholders, not management, and the value of this right is thus allocable to shareholders..$^{108}$

Related to these two arguments is the contention that MBOs can be viewed as a form of a venture capital transaction. Management's larger ownership and capacity to control the corporate enterprise incentivize them to act in an entrepreneurial manner. ${ }^{109}$ Even when they are not the primary

${ }^{100}$ See id. at 38-39; Modigliani \& Miller, supra note 84, at 284.

${ }^{101}$ See Kevin Amess, The Effect of Management Buyouts on Firm-Level Technical Inefficiency: Evidence from a Panel of UK Machinery and Equipment Manufacturers, 51 J. INDUS. ECON. 35, 35, 41 (2003) (finding that in a sample of MBO transactions from 1986-1997, the posttransaction enterprise had a higher efficiency rate during the first four years post buy-out).

${ }^{102}$ See id. at $35,42$.

${ }^{103}$ See Frank H. Easterbrook \& Daniel R. Fischel, Corporate Control Transactions, 91 YALE L.J. 698, 729 \& n.85 (1982).

${ }^{104} \mathrm{See}$ id.

${ }^{105}$ See id. at 732 (asserting that an offer premium at a "depressed" price would still produce a net gain to shareholders compared to an ordinary market return).

${ }^{106}$ See Coates, supra note 81 , at 13.

${ }^{107}$ See Andrei Shleifer \& Robert W. Vishny, Value Maximization and the Acquisition Process, J. ECON. PERSP., Winter 1988, at 7, 16 ("This claim that shareholders have the property right to all the firm's cash flows not allocated by an explicit contract is at the heart of many endorsements of hostile takeovers.").

${ }^{108}$ Romano, Management Buyout Puzzles, in LEVERAGED MANAGEMENT BuYOuTs: CAUSES AND CONSEQUENCES, supra note 16, at 199, 202 (discussing the theory that shareholders are the "rightful owners" of corporate information; therefore, management may not utilize this information for their own private gain in an MBO).

${ }^{109}$ See Robert L. Kieschnick, Jr., Management Buyouts of Public Corporations: An Analysis of Prior Characteristics, in LEVERAGED MANAGEMENT BUYOUTS: CAUSES AND CONSEQUENCES, supra note 16 , at $35,38-39$. 
capital provider, the release from agency costs and the better incentivizing compensation create opportunities for innovation. ${ }^{110}$ The gains and social wealth created by management are attributable to this conduct. ${ }^{111}$

Separately, there is the argument that management may be owed some of this premium in light of the risk they are accruing by leveraging the company. The increased debt and management ownership concentrates the wealth of the managers and creates excessive risk for them. ${ }^{112}$ Management is compensated for this risk through an outsize share of the takeover premium. ${ }^{113}$ The gains accrued are not the property of the shareholders, but rather surplus or created wealth. ${ }^{114}$

The argument that shareholder wealth is appropriated by managers is not mutually exclusive with the above arguments. This point is often addressed by the argument that the MBO process is subject to the general market for corporate control. ${ }^{115}$ If managers are indeed underbidding, this would be corrected in an efficient market by other interloping bids. ${ }^{116}$ These bidders would not be deterred by break fees, lock-ups, or the head start provided by management. ${ }^{17}$ This argument is truly an empirical one that has been the focus of prior research, which we discuss in the next subsection.

\section{Prior Studies of $M B O$ s}

In light of the countervailing theoretical arguments for and against these transactions, there have been surprisingly few studies since the $1980 \mathrm{~s}$ on the wealth effects of MBOs. To our knowledge, there are only two articles of significance in the last ten years examining this issue, and their results conflict. ${ }^{118}$ The first study found that "the stock percentage of a

${ }^{110}$ See Grundfest, supra note 16, at 242-43.

${ }^{11}$ See id.; Robert L. Kieschnick, Jr., Management Buyouts of Public Corporations: An Analysis of Prior Characteristics, in LEVERAGED MANAGEMENT BUYOUTS: CAUSES AND CONSEQUENCES, supra note 16, at 35, 37.

${ }^{112}$ Ramy Elitzur, et al., Managerial Incentives and the Structure of Management Buyouts, 36 J. ECON. BEH. \& ORG. 347, 363 (1998).

${ }^{113}$ Id. at $347,350,363$.

${ }^{114}$ See Easterbrook \& Fischel, supra note 103, at 731.

${ }^{115}$ See Henry G. Manne, Mergers and the Market for Corporate Control, 73 J. POL. ECON. $110,112-13$ (1965) (indicating that the market for corporate control has been theorized to provide a strong disciplining effect for managers).

${ }^{116}$ John C. Easterwood et al., Controlling the Conflict of Interest in Management Buyouts, 76 REV. ECON. STAT. 512, 513 (1994).

${ }^{117}$ See generally Paul Povel \& Rajdeep Singh, Takeover Contests with Asymmetric Bidders, 19 REV. FIN. STUD. 1399, 1402, 1415-16 (2006) (analyzing the effects and legality of deal protection devices).

${ }^{118}$ Chen et al., supra note 19 , at 1; Gogineni \& Puthenpurackal, supra note 17 , at 3. 
buyout manager team is negatively associated with the transaction premium."119 The authors cite this as "very strong evidence that buyout managers exploit shareholders." 120 In contrast, the second study found that, in a sample of completed MBO acquisitions from 1995 to 2007, management involvement in a takeover reduces pre-bidding competition. ${ }^{121}$ However, despite this reduction, the authors did not find any evidence indicating that target management involvement negatively affects shareholder returns throughout the announcement period. ${ }^{122}$

Prior to these recent studies, the evidence as to wealth effects was similarly mixed. Yakov Amihud surveyed the evidence prior to 1990 and conducted his own analysis. ${ }^{123}$ Amihud found that the "evidence on the premiums offered in MBOs does not support the hypothesis that management exploits the shareholders."124 Amihud's findings were later confirmed by a subsequent study. ${ }^{125}$ These findings, however, were contrary to a 1985 study by Louis Lowenstein. Lowenstein studied twenty-eight MBOs from 1979 to 1984, and found reduced premiums in MBOs without competitive bidding. ${ }^{126}$ Lowenstein cited these findings to argue for an open bidding regime in $\mathrm{MBOs}{ }^{127}$

The results of a study by Easterwood et al., which examined 184 MBOs from 1978 through 1988, lends support to Lowenstein's argument for open bidding. ${ }^{128}$ The authors found that "explicit competition for control" in

${ }^{119}$ Chen et al., supra note 19 , at 3.

${ }^{120} \mathrm{Id}$.

${ }^{121}$ Gogineni \& Puthenpurackal, supra note 17 , at 3.

${ }^{122}$ Id. at 5, 30; see also Jay C. Hartzell et al., What's in It for me? CEOs whose Firms are Acquired, 17 REV. FIN. STUD. 37, 37, 59 (2004) ("Regression estimates suggest that target shareholders receive lower acquisition premia in transactions involving extraordinary personal treatment of the CEO."). But see Leonce L. Bargeron et al., Are Acquisition Premiums Lower Because of Target CEOs' Conflicts of Interest? 1 (Charles A. Dice Ctr. for Research in Fin. Econ., Working Paper No. 2010-8, 2010), available at http://www.ssm.com/abstract=1593652 ("[T]arget CEO retention by the bidder does not appear to be driven by the CEO bargaining for his own interests at the expense of shareholders.").

${ }^{123}$ See Yakov Amihud, Leveraged Management Buyouts and Shareholders' Wealth, in LEVERAGED MANAGEMENT BUYOUTS: CAUSES AND CONSEQUENCES, supra note 16, at 3, 13-18.

${ }^{124}$ Id. at 19; see also Gailen L. Hite \& Michael R. Vetsuypens, Management Buyouts of Divisions and Shareholder Wealth, 44 J. FIN. 953, 969 (1989) ("[T]he evidence we present for a sample of 151 management buyouts of divisions during the period 1973-1985 indicates that, on average, parent company shareholders do not lose from such asset sales.").

${ }^{125}$ See Steven N. Kaplan, Sources of Value in Management Buyouts, in LEVERAGED MANAGEMENT BUYOUTS: CAUSES AND CONSEQUENCES, supra note 16, at 95, 100; see also Kaplan, supra note 25 , at 223 n.5.

\footnotetext{
${ }^{126}$ See Lowenstein, supra note 15 , at 736,738

${ }^{127} \mathrm{Id}$. at 731 .

${ }^{128}$ Easterwood et al., supra note 116 , at 512.
} 
the form of a competing bid resulted in higher bid revisions and cumulative abnormal returns for shareholders. ${ }^{129}$ This competition resulted in more shareholder aggregate wealth production than litigation or the effect of boards. ${ }^{130}$ Easterwood et al. also found that negotiations with independent directors improve bid revisions. ${ }^{131}$ At least one other study has found that directors can add value in the MBO process. ${ }^{132}$ A 1992 study by Lee et al. found that abnormal returns for shareholders of targets in MBOs are greater when boards are comprised primarily of independent directors. ${ }^{133}$

The evidence is similarly mixed on whether management times the buy-out process to its advantage, unduly manipulates the corporate process, or utilizes inside information to arrange an $\mathrm{MBO}$. DeAngelo found no evidence of manipulation of management earnings in a study of sixty-four firms from 1973 to $1982 .{ }^{134}$ Kaplan in his 1989 study found that managers consistently project outsized gains in their post-MBO forecasts. ${ }^{135}$ In contrast, a $2008 \mathrm{MBO}$ study found that management with greater external MBO financing tend to report significantly fewer abnormal accruals. ${ }^{136}$ This provides support for the argument that the board of directors and shareholders serve as weak gate-keepers of the MBO process. In his examination of the 1980s literature, Amihud found evidence that compared to other publicly traded companies, $\mathrm{MBO}$ firms showed inferior stock return performance in the period prior to announcement of the transaction. ${ }^{137}$

${ }^{129} I d$.

${ }^{130} \mathrm{Id}$.

${ }^{131} / d$. at 519.

${ }^{132}$ See Chun I. Lee et al., Board Composition and Shareholder Wealth: The Case of Management Buyouts, 21 FN. MGMT. 58, 60 (1992).

${ }^{133}$ Id. at 59 . Outside the MBO context there is also evidence that independent directors add value. See James F. Cotter et al., Do Independent Directors Enhance Target Shareholder Wealth During Tender Offers?, 43 J. FIN. ECON. 195, 201 (1997) (finding that in a sample of 169 tender offers from 1989 to 1992 independent directors are associated with increased share premium and corporate independence); see also Stuart Rosenstein \& Jeffrey G. Wyatt, Outside Directors, Board Independence, and Shareholder Wealth, 26 J. FIN. ECON. 175, 176 (1990) ("The empirical results indicate that the appointment of an outside director is accompanied, on average, by significantly positive excess returns ....").

${ }^{134}$ DeAngelo, supra note 76 , at 401 .

${ }^{135}$ See Kaplan, supra note 25 , at 248 ("[O]nly $37.5 \%$ and $28.0 \%$ of the buyout companies meet the projections provided in the proxy statement in the first and second full years after the buyout.").

${ }^{136}$ Paul E. Fischer \& Louis Henock, Financial Reporting and Conflicting Managerial Incentives: The Case of Management Buyouts, 54 MGMT. SCI. 1700, 1713 (2008).

${ }^{137}$ Yakov Amihud, Leveraged Management Buyouts and Shareholders' Wealth, in LEVERAGED MANAGEMENT BUYOUTS: CAUSES AND CONSEQUENCES, supra note 16, at 3, 20; see also D. Scott Lee, Management Buyout Proposals and Inside Information, 47 J. FIN. 1061, 1063 (1992). 
As for the motivations of managers in MBOs, there are only a handful of studies from the 1980s on this issue. Louis Lowenstein argued that MBO transactions were mainly motivated by tax considerations and market pricing anomalies. ${ }^{138} \mathrm{Kaplan}$ found that MBOs produce large returns $-80 \%$ above market average. ${ }^{139} \mathrm{He}$ concluded that these returns were produced by tax benefits and operational efficiencies. ${ }^{140}$ Ivan Bull studied MBOs from 1980 to 1983 and, contrary to Lowenstein, found that tax effects did not drive MBOs, but rather that the more entrepreneurial post-MBO management produced the lion's share of MBO gains. ${ }^{141}$ Amihud also disputed Lowenstein's conclusions on the basis that net revenues to the government may be unchanged due to taxpayer payments on capital gains, and in any event, these benefits could be realized outside the MBO context. ${ }^{142}$

Other studies have come to contradictory conclusions about the explanations for MBOs. Kieschnick argued that the $\mathrm{MBO}$ is a "risky arbitrage" event which involves a restructuring of the company to release break-up value. ${ }^{143}$ DeAngelo et al. argued that MBOs are a result of a desire to avoid the costs of being public, an argument which was revived in the wake of Sarbanes-Oxley. ${ }^{144}$ A review of existing studies also finds that the data collection and analysis is heterogeneous. Some studies include MBOs of private and public companies. Yet, in the private company analysis, the agency monitor problem present in the public company context does not exist, as the selling company can provide this function.

\footnotetext{
${ }^{138}$ Lowenstein, supra note 15 , at 731, 739-40.

${ }^{139}$ Steven N. Kaplan, Sources of Value in Management Buyouts, in LEVERAGED MANAGEMENT BUYOUTS: CAUSES AND CONSEQUENCES, supra note 16, at 95, 98.

${ }^{140}$ Kaplan, supra note 25, at 219-20; see also Steven N. Kaplan, Sources of Value in Management Buyouts, in LEVERAGED MANAGEMENT BUYOUTS: CAUSES AND CONSEQUENCES, supra note 16 , at $95,98-99$.

${ }^{141}$ Ivan Bull, Management Performance in Leveraged Buyouts: An Empirical Analysis, in LEVERAGED MANAGEMENT BUYOUTS: CAUSES AND CONSEQUENCES, supra note 16, at 69, 89; see also Chris J. Muscarella \& Michael R. Vetsuypens, Efficiency and Organizational Structure: $A$ Study of Reverse LBOs, 45 J. FIN. 1389, 1412 (finding that the post-LBO governance structure produces a substantial part of post-transaction gains to LBO participants) (1990); Abbie J. Smith, Corporate Ownership Structure and Performance: The Case of Management Buyouts, 27 J. FIN. ECON. 143, 144 (1990).

${ }^{142}$ Yakov Amihud, Leveraged Management Buyouts and Shareholders' Wealth, in LEVERAGED MANAGEMENT BUYOUTS: CAUSES AND CONSEQUENCES, supra note 16, at 3, 26.

${ }^{143}$ Robert L. Kieschnick, Jr., Management Buyouts of Public Corporations: An Analysis of Prior Characteristics, in LEVERAGED MANAGEMENT BUYOUTS: CAUSES AND CONSEQUENCES, supra note 16 , at $35,40-41$.

${ }^{144}$ Harry DeAngelo et al., Going Private: Minority Freezeouts and Stockholder Wealth, 27 J.L. \& ECON. 367, 400 (1984). For an examination of this argument in a post-Sarbanes-Oxley world, see Christian Leuz et al., Why do Firms go Dark? Causes and Economic Consequences of Voluntary SEC Deregistrations, 45 J. ACCT. \& ECON. 181, 182 (2008).
} 
The end result is that, as of 2011, it is still uncertain whether MBOs are detrimental to shareholder wealth or even appropriate for heightened regulation. But as the Bankrate deal illustrates, MBOs are not identical. Some are structured to address this fundamental agency conflict while others appear to pay a more deferential approach to acquirers, allowing for higher lock-ups and lacking provisions such as majority of minority provisions, which empower shareholders. The wealth effects of MBOs may be attributable in part to the value of the corporate process imposed on these transactions. This Study examines that issue.

\section{THE ROLE OF PROCESS IN MBOS}

\section{A. The Regulation of Conflicts in Takeovers}

The mitigation of agent/principal conflict is a key goal of corporate law, one identified by the Berle-Means hypothesis in 1932. ${ }^{145}$ Owners are separated from control of the corporate enterprise, which is then delegated to directors and managers by shareholders. ${ }^{146}$ This separation of ownership from control raises numerous overt and embedded conflicts, as management derives its own private benefits and rents from this division.

Corporate law has evolved to address these issues through statutory and court regulation, such as by restrictions on self-dealing and the corporate opportunity doctrine. In the takeover process, conflicts have largely been addressed through both process and court substantive review. Historically, this process has been guided by state laws on self-dealing transactions. ${ }^{147}$ With respect to self-dealing, corporate law generally permits these transactions to occur provided they are approved by (1) disinterested directors, (2) disinterested shareholders, or (3) are otherwise found by a court to be entirely "fair" to a corporation. ${ }^{148}$ These statutes adopt a bifurcated approach: conflict transactions could be approved through either procedural means (disinterested director or shareholder approval) or substantive review (by a court ex post facto for faimess). ${ }^{149}$

\footnotetext{
${ }^{145}$ ADOLF A. BERLE, JR. \& GARDINER C. MEANS, THE MODERN CORPORATION AND PRIVATE PROPERTY 117-18 (1932).

${ }^{146}$ Id.

${ }^{147}$ Peter E. Kay, Director Conflicts of Interest Under the Model Business Corporation Act: A Model for All States?, 69 WASH. L. REV. 207, 209 (1994) ("[S]tates began to enact statutes specifically addressing officer and director conflict of interest transactions ... [beginning] in 1931.").

${ }^{148}$ See, e.g., DEL. CODE ANN. tit. 8, § 144(a)(1)-(3) (2001 \& Supp. 2010).

${ }^{149}$ See generally Kay, supra note 147, at 208-10 (reviewing various forms of conflicted
} 
Until the 1970s it was largely thought that either approach could be taken when self-dealing conflict arose in the acquisition process. ${ }^{150}$ During this time, however, a number of squeeze-out transactions drew attention to the substantive review prong. The concern was that the position of controlling shareholders rendered procedural safeguards meaningless or otherwise violated the public trust doctrine. ${ }^{151}$ A number of academic studies and SEC proposals at the time called for these transactions to be regulated by either substantive review (through court process) or exogenous procedural and substantive safeguards, such as independent investment banker review. ${ }^{152}$

\section{B. The Regulation of Freeze-outs}

The issue burned through the Delaware courts until 1983 when in Weinberger v. UOP, Inc., the Delaware Supreme Court definitively decided for a substantive approach. ${ }^{153}$ Henceforth, freeze-outs would be regulated by courts, and controlling shareholders would be subject to non-waivable "entire fairness" and ex post facto review. ${ }^{\text {s4 }}$ To this substantive requirement was added a procedural gloss: controlling shareholders could shift the burden of having to prove "entire fairness" onto challenging shareholders by

\footnotetext{
interest transaction statutes and their structure).

${ }^{150}$ See id. at 208-09 ("[T] he courts were uncertain of the requirements necessary to preclude [substantive review] ....").

${ }^{151}$ See Brudney, supra note 21, at 1019-20.

${ }^{152}$ See, e.g., id. at 1038-39 (advocating for prohibition of going-private transactions, and absent this remedy, for heightened procedural standards, including increased disclosure requirements); Brudney \& Chirelstein, supra note 15, at 1376 (advocating for judicial review for "fairness" rather than a "business purpose" requirement); Greene, supra note 21, at 506-11 (advocating varying substantive and procedural rules depending upon the nature of the going-private transaction, including administrative review of the going-private transaction for faimess); Edmund H. Kerr, Going Private: Adopting a Corporate Purpose Standard, 3 SEC. REG. L.J. 33, 57-60 (1975) (rejecting the new SEC proposals to regulate going-private transactions, and arguing that the state law "corporate purpose" test provided adequate remedies for plaintiffs); Anne Jentry, Note, The Developing Law of Corporate Freeze-outs and Going Private, 7 LOY. U. CHI. L.J. 431, 456-58 (1976) (concluding that rather than federal securities rules promulgated by the SEC, state law remedies of "fairness" and "a business purpose" should be the only rule governing going-private transactions in the absence of Congressional action on the subject); F. Hodge O'Neal \& Ronald R. Janke, Utilizing Rule 10b-5 for Remedying Squeeze-outs or Oppression of Minority Shareholders, 16 B.C. INDUS. \& COM. L. REV. 327, 327, 346 (1975) (discussing the utility of $\$ 10(b)$ of the Securities Exchange Act and concluding that it would provide a proper remedy for minority shareholders in going-private transactions); Note, Going Private, 84 YALE L.J. 903,930 (1975) ("[C]ourts should therefore examine going private attempts closely for signs of failure by corporate insiders to maintain their fiduciary obligations to the minority.").

${ }^{153}$ Weinberger v. UOP, Inc., 457 A.2d 701, 714 (Del. 1983).

${ }^{154}$ Id. at 714-15.
} 
allowing a special committee of independent directors to approve the transaction. ${ }^{155}$

This approach was upset at the turn of the millennium by a series of decisions in the Delaware Chancery Court. In the Siliconix and Pure Resources opinions, Delaware courts held that a majority shareholder could freeze-out and acquire a minority shareholding, avoiding "entire fairness" review if the acquisition was via tender offer rather than merger. ${ }^{156}$ The business judgment rule would apply and the court would not second-guess the sale price or process so long as certain requisites of process were followed, including consideration by a special committee of independent directors, and the inclusion of a non-coercive majority of minority condition in the tender offer. ${ }^{157}$ A controlling shareholder who otherwise followed certain procedural mechanisms could thus avoid "entire fairness" review. ${ }^{158}$

This new turn by Delaware was largely endorsed by academics and coincided with the embrace by the academy of independent directors as a model of good corporate governance. Gilson and Gordon wrote that procedural mechanisms which mimic arms-length bargaining should forestall "entire fairness" review in the controlling shareholder situation. ${ }^{159}$ The argument fits within an evolving consensus that procedural mechanisms, such as independent directors and special committees, could adequately substitute for substantive court review. ${ }^{160}$

The empirical evidence was less robust. Two subsequent studies on the effect of these decisions came to differing conclusions on the value of this new process in corporate freeze-outs. One study, by Guhan Subramanian, found "strong evidence that minority shareholders receive

${ }^{155}$ Kahn v. Lynch Comm'cn Sys., Inc., 669 A.2d 79, 82 (Del. 1995).

${ }^{156}$ In re Siliconix Inc. S'holders Litig., 2001 WL 716787, at *6-*8(Del. Ch. June 19, 2001), reprinted in 27 DEL. J. CORP. L. 1011, 1021-24 (2002); In re Pure Res., Inc. Stholders Litig., 808 A.2d $421,424,428$ (Del. Ch. 2002).

${ }^{157}$ See Ronald J. Gilson \& Jeffrey N. Gordon, Controlling Controlling Shareholders, 152 U. PA. L. REV. 785, 839-40 (2003).

${ }^{158}$ See id. at 800 .

${ }^{159} \mathrm{Id}$.

${ }^{160}$ See also A.C. Pritchard, Tender Offers by Controlling Shareholders: The Specter of Coercion and Fair Price, 1 BERKELEY BUS. L.J. 83, 111 (2004) (arguing that courts should limit their review of going-privates in the absence of a coercive offer or a retributive threat since marketmechanisms will compensate minority shareholders for the loss of an "entire fairness" regime); Subramanian, supra note 23, at 63-64 (arguing for convergence in judicial standards for freeze-outs and a requirement of special committee approval and a majority of the minority condition in order for courts to apply the business judgment rule to a going-private); Faith Stevelman, Going Private at the Intersection of the Market and the Law, 62 Bus. LAw. 775, 910-11 (2007) ("In pursuing a freeze-out, controllers should either truly empower the committee to negotiate at arms' length or their transaction should be subject to scrutiny for fairness in the event of a shareholder challenge."). 
lower [cumulative abnormal returns] in tender-offer freeze-outs than in statutory merger freeze-outs." ${ }^{161}$ A second study, by Thomas W. Bates et al., found that "the evidence does not support the view that potential conflicts of interest during freeze-out transactions result in disproportionate allocations of deal surplus to controlling shareholders."162

These two studies were confined to the "freeze-out" procedure, and did not examine other attributes of procedural and substantive protections, such as an open bidding process, contractual protections in acquisition agreements, the situs of corporate organization, and shareholder litigation. ${ }^{163}$ These studies thus do not address the role of these protections in MBOs and other areas of director, officer, and shareholder conflict in takeovers.

\section{The Regulation of $M B O s$}

In contrast to freeze-outs, there has been very little case-law addressing the proper regulation of MBOs. The only Delaware judicial opinion to do so is then-Vice Chancellor Jacob's 1995 opinion in In re Wheelabrator Technologies, Inc. Shareholders Litigation. ${ }^{164}$ In that decision, the Vice Chancellor ${ }^{165}$ rejected an argument that MBOs should be reviewed under the heightened standard of "entire fairness," as is used in freeze-outs. ${ }^{166}$ Instead, he found that the procedural protection embedded in the Delaware conflict of interest transaction statute was sufficient to regulate these transactions. ${ }^{167}$ Approval by the independent directors or disinterested shareholders was sufficient to purge the conflict of interest in an MBO transaction and remove the need for substantive court review for "entire faimess." 168

Though the Delaware Supreme Court has not addressed this issue, post-Wheelabrator practitioners have structured MBOs under the

${ }^{161}$ Guhan Subramanian, Post-Siliconix Freeze-Outs: Theory and Evidence, 36 J. LEGAL STUD. 1, 23 (2007).

${ }^{162}$ Thomas W. Bates et al., Shareholder Wealth Effects and Bid Negotiation in Freeze-out Deals: Are Minority Shareholders Left Out in the Cold?, 81 J. FIN. ECON. 681, 683 (2006).

${ }^{163}$ See id. at 682-84; Subramanian, supra note 161, at 2.

${ }^{164}$ In re Wheelabrator Techs. Inc. S'holders Litig., 663 A.2d 1194 (Del. Ch. 1995).

${ }^{165}$ Now a Justice on the Delaware Supreme Court.

${ }^{166} I d$. at 1205 ("The plaintiffs argue that their duty of loyalty claim is governed by the entire faimess standard.... That is incorrect, because this merger did not involve an interested and controlling stockholder.").

${ }^{167} I d$. at $1205 \&$ n. 8 .

${ }^{168}$ This assumes that management has less than a controlling interest in the organization; otherwise the entire fairness doctrine will apply as this becomes a controlling shareholder freeze-out transaction. 
assumption that they are not subject to heightened review provided the procedural elements of Delaware's conflict of interest statute are satisfied. ${ }^{169}$ If another Delaware court considered the issue, it is not likely to adopt a heightened judicial review standard given the Delaware judiciary's current preference for ex ante procedure to ameliorate agency conflict in the acquisition context. By not subsequently reviewing the rulings in Siliconix and Pure Resources, the Delaware courts have implicitly endorsed this procedural turn. In this vein, the Delaware courts have continued to push procedural mechanisms as an appropriate remedy to ameliorate manager/shareholder conflicts. In In re John Q. Hammons Hotels Inc. Shareholder Litigation, decided in 2009, the Delaware Court of Chancery held that a controlling shareholder could receive private benefits in a change of control transaction that involved a third-party acquisition, provided that there was a non-waivable majority of minority condition in the acquisition agreement. ${ }^{170}$ This is yet another endorsement of ex ante procedural protections over ex post facto substantive court review of transactions in Delaware.

This endorsement has recently received yet another judicial affirmation. In In re CNX Gas Corp. Shareholders Litigation, Vice Chancellor Laster further modified the requirements under Siliconix and Pure Resources for controlling shareholders to qualify for business judgment review of a freeze-out transaction undertaken through a tender offer. ${ }^{171}$ Vice Chancellor Laster held that to qualify for business judgment review of a freeze-out transaction via a tender offer, a controlling shareholder was required to actually obtain the agreement of a special committee of independent directors to the transaction. ${ }^{172}$ This holding goes beyond the dictate in Pure Resources that the controller merely needed to allow the committee to recommend for or against the transaction. ${ }^{173}$ This turn marks a new contention in Delaware law, as the courts embrace procedural

\footnotetext{
${ }^{169}$ See, e.g., Andrew R. Brownstein et al., Management Buyouts and the Duties of Independent Directors to Shareholders and Creditors, in FOURTH ANNUAL PRIVATE EQUITY FORUM: LEGAL \& FINANCIAL STRATEGIES FOR DEALMAKING IN THE CURRENT MARKET 597, 599 (Practising Law Institute Corporate Law and Practice Course Handbook Series 2002) ("In practice, this means that each buyout proposal, where management or a controlling stockholder is a leading participant, must be evaluated by noninterested directors and independent financial and legal advisors in order for the board to avoid having to prove that the transaction meets the rigorous standards of 'entire fairness."').

${ }^{170}$ In re John Q. Hammons Hotels Inc. S'holder Litig., 2009 WL 3165613, at *12 (Del. Ch. Oct. 2, 2009), reprinted in 35 DEL. J. CORP. L. 621, $639-40$ (2010).

${ }_{171}^{17}$ re CNX Gas Corp. S'holders Litig., 4 A.3d 397, 407, 413-14 (Del. Ch. 2010).

${ }^{172}$ Id. at $412-13,415$.

${ }^{173}$ See id.
} 
requirements in conflicted interest transactions, but still debate what their appropriate parameters should be.

\section{Normative Protections in MBO Transactions}

The statutory conflict standards for MBOs in light of the Wheelabrator opinion have been supplemented by a set of normative protections. These norms are a response to this regulation and the channeling process it creates. ${ }^{174}$ These protections go beyond what Delaware and other states require, and are often implemented in response to best practices put forth by academics and proxy ratings agencies. They create a contractual structure that is bargained over by boards and $\mathrm{MBO}$-sponsors, and is designed to protect and empower shareholders in the MBO process. They consist of both substantive and procedural devices:

Special Committee of Independent Directors. Committees of independent directors are formed to consider these transactions. ${ }^{175}$ In order to buttress their independence, these committees typically retain their own set of legal and financial advisors to assist them in considering and negotiating the transaction. ${ }^{176}$

Majority of the Minority Condition. This requirement placed in the acquisition agreement specifies that approval of the transaction shall be by a majority of the disinterested or unaffiliated shareholders. ${ }^{177}$ Like the independent director requirement it is formulated in regard to conflict of interest statutes. This is generally a higher requirement than the fifty-percent shareholder approval requirement to approve a merger since it excludes shares held by management and other interested parties. This condition can be formulated in two ways: (1) as a majority of those voting, or (2) of the

${ }^{174}$ See Edward B. Rock, Saints and Sinners: How Does Delaware Corporate Law Work?, 44 UCLA L. REV. 1009, 1018-19, 1023-24, 1063 (1997) (citing MBO decisions in Delaware courts to argue that the Delaware judiciary uses fiduciary duties to create social norms to govern future actors).

${ }^{175}$ Scott V. Simpson, The Emerging Role of the Special Committee-Ensuring Business Judgment Rule Protection in the Context of Management Leveraged Buyouts and Other Corporate Transactions Involving Conflicts of Interest, 43 BUS. LAW. 665, 678 (1988).

${ }^{176}$ See James D. Cox, Managing and Monitoring Conflicts of Interest: Empowering the Outside Directors with Independent Counsel, 48 VILL. L. REV. 1077, 1084, 1086 (2003) ("In making their assessment, the outside directors who constitute the special litigation committee rely heavily on their advisors, most importantly the committee's counsel who is sometimes joined by other consultants.").

${ }^{177}$ See Donald J. Wolfe, Jr., The Odd Couple: Majority of Minority Approval and the Tender Offer, M\&A LAW., Nov.-Dec. 2002, available at http://www.potteranderson.com/newspublications-0-51.html. 
entire outstanding minority shareholder base. The latter formulation is a more powerful shareholder check on the MBO transaction since it has a higher threshold of shareholder approval. ${ }^{178}$ In MBO transactions, these conditions are less likely to be negotiated since in many instances the interested management stake is well below a majority control level, and therefore the need for this condition is diminished. ${ }^{179}$

Reduced Lock-ups. Lock-ups are normative contractual devices which are designed to compensate an initial bidder in an ordinary change of control context. ${ }^{180}$ In an MBO, these devices are sometimes reduced or eliminated. This theoretically should permit more active third-party bidding for the MBO target as it eliminates or reduces potentially preclusive lock-ups. The main type of lock-up typically at issue in an MBO is the breakup or termination fee. The amount of a termination fee is typically limited by Delaware law and normative practices to approximately three-percent of the transaction value,${ }^{181}$ though in some circumstances Delaware has allowed lock-ups that exceed this amount. ${ }^{182}$ In an MBO transaction, this breakup fee is sometimes reduced below this amount or eliminated in order to create more open bidding.

Auctions. This is a pre-announcement procedure whereby a company, usually through its retained financial advisors, auctions itself. The goal is to

\footnotetext{
${ }^{178}$ See id. ("[T]he adoption of a condition that the merger will be consummated only upon the affirmative vote of a majority of the shares owned by holders unaffiliated with the controlling stockholder ... has been judicially recognized as sufficient to neutralize the inherent power of a controlling stockholder unilaterally to achieve board and stockholder approval of a transaction that serves its unilateral interest to the detriment of the minority.").

${ }^{179}$ While we refer to these conditions as majority of minority conditions, in these instances the conditions are more aptly termed a "majority of the unaffiliated shareholders" since the minority is actually in the majority in such circumstances. In this study we use the term "majority of minority" to refer to both types of conditions.

${ }^{180}$ See generally John C. Coates IV \& Guhan Subramanian, A Buy-Side Model of M\&A Lockups: Theory and Evidence, 53 STAN. L. REV. 307, 311, 314 (2000) (discussing different forms of lockup provisions, including stock lockups, asset lockups, and breakup fees). In addition to these types of lock-ups there are also procedural lock-ups such as matching rights, information rights, and standstill requirements. Beyond the specific procedural lock-ups addressed in this article we do not address the impact of these other types of procedural lock-ups.

${ }^{181}$ See generally Frederick H. Alexander, Mergers and Acquisitions-A Delaware Checklist, in MERGERS \& ACQUiSITIONS 2008: WHAT YOU NEED TO KNOW Now 69, 106-09 (Practising Law Institute Corporate Law and Practice Course Handbook Series 2008) (discussing Delaware courts' approval of termination fees expressed as a percentage of the total deal value); see also Brian JM Quinn, Optionality in Merger Agreements, 35 DEL. J. CORP. L. 789, 805-09 (2010) (discussing Delaware courts' treatment of termination fees as limited by fiduciary duties);

${ }^{182}$ E.g., In re Toys "R" Us, Inc. S'holder Litig., 877 A.2d 975, 980, 1021 (Del. Ch. 2005) (upholding a termination fee equivalent to 3.75 percent of the target's equity value).
} 
maximize pricing and bidding for the company. In the MBO context, an auction is also a part of the open bidding process.

Go-shop. This device was discussed in Part I. ${ }^{183}$ A go-shop purportedly substitutes for a pre-announcement auction process by allowing a post-auction solicitation of offers for the company after announcement of the initial takeover transaction. ${ }^{184}$

All of these mechanisms have their flaws, drawbacks, and complexities. For example, in the case of an independent committee, the question is how independent must the committee be? ${ }^{185}$ A director who meets the legal standards is still subject to heuristic biases and other conflicts which could force him or her to unintentionally favor a management bidding group. ${ }^{186}$ There is a lack of consensus on just how independent these directors need to be, both in general and for purposes of assessing the MBO transaction. ${ }^{187}$

Go-shops have been viewed as cosmetic and enabling management to paper over the head start they gain in announcing a transaction with an agreement and without an auction. ${ }^{188}$ Meanwhile, the auction processes can be subtly manipulated through the information provided, potential bidder awareness of management preferences, and the initial bidders contacted. ${ }^{189}$

To our knowledge, the role of ex ante court review of these devices when used in MBOs has yet to be examined. Ultimately, the question is whether these processes add value and if that value is warranted in an MBO.

${ }^{183}$ See supra notes 54-61 and accompanying text.

${ }^{184}$ See supra notes 54-61 and accompanying text.

${ }^{185}$ See Deborah A. DeMott, Puzzles and Parables: Defining Good Faith in the MBO Context, 25 WAKE FOREST L. REV. 15, 32-34 (1990) (discussing Delaware case-law on the proper level of independence of directors in MBOs).

${ }^{186}$ See Antony Page, Unconscious Bias and the Limits of Director Independence, $2009 \mathrm{U}$. ILL. L. REV. 237, 239-40 (2009) (arguing that directors suffer from cognitive biases which limit their ability to serve an independent director function).

${ }^{187}$ See William T. Allen, Independent Directors in MBO Transactions: Are They Fact or Fantasy?, 45 BUS. LAW. 2055, 2056-60 (1990) (explaining the "dichotomy of views" in Delaware courts with respect to the level of independence required of directors and whether independent directors can adequately challenge management when it proposes an $\mathrm{MBO}$ ).

${ }^{188}$ See supra notes 54-61 and accompanying text.

${ }^{189}$ See Stephen M. Bainbridge, Exclusive Merger Agreements and Lock-Ups in Negotiated Corporate Acquisitions, 75 MINN. L. REV 239, 328, 329-30 (1990). 


\section{THE ROLE OF PROCESS IN MBOS (2003-2009)}

\section{A. Data Collection}

To examine the value of process in MBOs, we began by collecting all transactions announced between 2003 and 2009 with a transaction value greater than $\$ 10$ million and flagged as an MBO in the MergerMetrics or Thomson Reuters databases. We find there is substantial overlap between the transactions listed in the two databases, but not all transactions represented in one are found in the other. We have supplemented these databases by searching through all Rule $13 \mathrm{e}-3$ filings on $10 \mathrm{~K}-\mathrm{Wizard}{ }^{190}$ and adding to our sample all such transactions between 2003 and 2009 which involve management affiliation. ${ }^{191}$

Next, we excluded transactions that were either incorrectly flagged or for which an acquisition agreement was never executed, or which otherwise did not fit within the sample parameters. We arrived at a sample of 103 transactions. We then reviewed proxy statements, merger agreements, and other publicly available information on these transactions to code contractual terms; bidding rates; management participation; benefits and post-transaction ownership; and the use of procedural and substantive protections like independent committees of directors. In addition, we compiled from court records and other publicly available information an extensive record of litigation rates and outcomes, in order to measure the effect of litigation on MBO outcomes. We also coded other important characteristics of transactions, such as target incorporation locales and attorneys for targets.

In collecting this data, we found that these databases are not identical in their MBO coding. In particular, the databases do not reliably code as MBOs, transactions which have management participation. We thus believe that by reviewing all databases, as well as Rule $13 \mathrm{e}-3$ transactions, we have created a more definitive sample.

\section{B. Descriptive Statistics}

The sample we have created provides a wealth of information about MBO transactions, and it provides a comprehensive view of the

\footnotetext{
${ }^{190}$ The $10-\mathrm{K}$ Wizard is a Morningstar document research product available by subscription at http://www.10kwizard.com.

${ }^{191}$ A Schedule 13e-3 must be filed for all transactions classified as "going-private" transactions under Rule 13e-3 of the Securities Exchange Act of 1934. 17 C.F.R. $\$ 240.13 \mathrm{e}-3$ (d)(1) (2008).
} 
characteristics of these transactions. We begin by setting forth, in Table I, basic descriptive statistics describing the characteristics of management involvement in these transactions. We do so in order to set a basis in the next section for examining, on a more sophisticated econometric basis, how management involvement affects the MBO process.

Table I. Sample Descriptive Statistics

Table I sets forth descriptive statistics on 103 transactions announced from 2003 through 2009, either (1) coded as an MBO in MergerMetrics or Thomson/Reuters, or (2) for which a Schedule $13 \mathrm{e}-3$ was filed with the SEC, indicating significant management involvement in the buyout group. The sample is limited to buyouts with a transaction value of at least $\$ 10$ million and a publicly-traded target. It is also limited to buyouts for which a merger agreement is signed and publicly disclosed. Both completed and withdrawn buyouts are included. "Transaction Value" is the total value offered to acquire the outstanding common stock of the target. "Enterprise Value" (EV) equals transaction value plus net debt. "Initial Offer Premium at Announcement" and "Ultimate Premium Paid at Closing" are over target's trading price sixty days prior to merger announcement.

Table I

\begin{tabular}{|l|c|}
\hline Panel A: Transaction Parties & $\%$ \\
\hline Outside Capital Participant & $73.8 \%$ \\
\hline Private Equity Participant & $71.8 \%$ \\
\hline Mgmt is Only Acquiring Party & $26.2 \%$ \\
\hline Structured by PE Firm & $55.3 \%$ \\
\hline Structured by Target Directors \& Officers & $44.7 \%$ \\
\hline $\begin{array}{l}\text { Announcement of Mgmt. Offer Before } \\
\text { Agreement }\end{array}$ & $29.4 \%$ \\
\hline \multicolumn{2}{|l|}{} \\
\hline Initiating Entity: & $44.1 \%$ \\
\hline Interested Directors \& Officers & $26.5 \%$ \\
\hline Third Party & $24.5 \%$ \\
\hline Board & $4.9 \%$ \\
\hline Investment Bank & \\
\hline
\end{tabular}




\begin{tabular}{|c|c|c|c|c|}
\hline & Min & Mean & Median & Max \\
\hline $\begin{array}{l}\text { Interested Mgmt. } \\
\text { Pre- Ownership }\end{array}$ & $0.0 \%$ & $20.5 \%$ & $13.4 \%$ & $88.1 \%$ \\
\hline $\begin{array}{l}\text { Interested D\&O } \\
\text { Pre- Ownership }\end{array}$ & $0.4 \%$ & $25.2 \%$ & $17.8 \%$ & $88.1 \%$ \\
\hline $\begin{array}{l}\text { All D\&O Pre- } \\
\text { Ownership }\end{array}$ & $0.9 \%$ & $32.8 \%$ & $29.9 \%$ & $87.8 \%$ \\
\hline $\begin{array}{l}\text { Interested D\&O } \\
\text { Post-Ownership }\end{array}$ & $2.7 \%$ & $46.0 \%$ & $31.9 \%$ & $100.0 \%$ \\
\hline $\begin{array}{l}\text { CEO Post- } \\
\text { Ownership }\end{array}$ & $0.0 \%$ & $21.9 \%$ & $6.1 \%$ & $100.0 \%$ \\
\hline $\begin{array}{l}\text { Interested D\&O } \\
\text { Stock Cash-Out } \\
(\$ \mathrm{~mm})\end{array}$ & $\$ 0.0$ & $\$ 52.2$ & $\$ 2.8$ & $\$ 1,447.7$ \\
\hline $\begin{array}{l}\text { Interested D\&O } \\
\text { Options Cash-Out } \\
(\$ \mathrm{~mm})\end{array}$ & $\$ 0.0$ & $\$ 11.9$ & $\$ 0.2$ & $\$ 224.5$ \\
\hline $\begin{array}{l}\text { Interested D\&O } \\
\text { Bonus (\$mm) }\end{array}$ & $\$ 0.0$ & $\$ 1.1$ & $\$ 0.0$ & $\$ 19.3$ \\
\hline $\begin{array}{l}\text { Total Cash-Out } \\
(\$ \mathrm{~mm})\end{array}$ & $\$ 0.0$ & $\$ 64.3$ & $\$ 7.7$ & $\$ 1,541.7$ \\
\hline $\begin{array}{l}\text { Total Cash-Out } \\
(\% \text { of EV) }\end{array}$ & $0.0 \%$ & $6.5 \%$ & $2.4 \%$ & $53.9 \%$ \\
\hline
\end{tabular}

In $73.8 \%$ of transactions, management partners with a secondary capital provider that is often the controlling acquirer. In $71.8 \%$ of deals, this capital provider is a private equity firm. In only $26.2 \%$ of transactions is management the only acquiring party. In only about one-third of all transactions does management have a post-transaction interest that constitutes control of the corporate enterprise, reflecting management's often limited participation. 
These figures show the difficulty in defining and differentiating between MBOs and MBIs. MBOs can be defined as transactions in which management acquires a controlling post-transaction ownership interest in the company. ${ }^{192}$ However, this does not capture takeovers where management can be deemed to be the organizing or initiating party for the transaction. In our sample and from review of proxy statements associated with these transactions, we find that $44.1 \%$ of transactions are initiated by management, and in $44.7 \%$ of transactions management is involved in the negotiating group. In Part $\mathrm{V}$, we further discuss this issue and offer definitions of MBOs and MBIs based on our findings.

The figures in Table I also descriptively support the conventional wisdom concerning agency conflict in MBOs and the ability of management to immediately profit from these transactions. MBOs are opportunities for management to monetize a portion of their holdings while retaining a significant stake in the post-transaction enterprise. On average, directors and officers increase their ownership stake by $20.8 \%$ while receiving an average payment per transaction of $\$ 64.3$ million. More specifically, in our sample the median cash proceeds paid to directors and officers interested in the transaction is $\$ 7.7$ million, with a maximum of $\$ 1.5$ billion. The median pre-transaction ownership of interested directors and officers is $17.8 \%$ with a maximum pre-transaction ownership of $88.1 \%$. The median for CEO posttransaction ownership is $6.1 \%$, with a maximum of $100 \%$. The median for total interested director and officer post-transaction ownership is $31.9 \%$, with a maximum of $100 \%$.

Table II. Contract Structure of MBOs

In Table II we set forth descriptive statistics describing the contract structure of MBO transactions in our sample:

Table II

\begin{tabular}{|l|c|c|}
\hline \multicolumn{3}{|l|}{ Panel A: } \\
\hline & N & $\%$ \\
\hline Special Committee & 90 & $87.4 \%$ \\
\hline Go-Shop Provision & 28 & $23.5 \%$ \\
\hline
\end{tabular}

${ }^{192}$ See supra Part I. 


\begin{tabular}{|c|c|c|c|c|}
\hline $\begin{array}{l}\text { Matching Offer } \\
\text { Period (Yes) }\end{array}$ & \multicolumn{2}{|c|}{76} & \multicolumn{2}{|c|}{$80.9 \%$} \\
\hline $\begin{array}{l}\text { Majority of Minority } \\
\text { Condition (All) }\end{array}$ & \multicolumn{2}{|c|}{19} & \multicolumn{2}{|c|}{$18.5 \%$} \\
\hline $\begin{array}{l}\text { Majority of Minority } \\
\text { Condition (Voting) }\end{array}$ & \multicolumn{2}{|c|}{14} & \multicolumn{2}{|c|}{$13.6 \%$} \\
\hline $\begin{array}{l}\text { Termination Fee } \\
\text { (Yes) }\end{array}$ & \multicolumn{2}{|c|}{99} & \multicolumn{2}{|c|}{$96.1 \%$} \\
\hline \multicolumn{5}{|l|}{ Panel B: } \\
\hline & Min & Mean & Median & Max \\
\hline $\begin{array}{l}\text { Go-Shop Window } \\
\text { (Days) }\end{array}$ & 18 & 36 & 35 & 60 \\
\hline $\begin{array}{l}\text { Matching Offer } \\
\text { Period (Days) }\end{array}$ & 1 & 4 & 4 & 10 \\
\hline $\begin{array}{l}\text { Termination Fee } \\
(\$ \mathrm{~mm})\end{array}$ & $\$ 0.3$ & $\$ 29.6$ & $\$ 10.2$ & $\$ 500.0$ \\
\hline $\begin{array}{l}\text { Termination Fee }(\% \\
\text { of Transaction } \\
\text { Value) }\end{array}$ & $0.2 \%$ & $3.7 \%$ & $3.2 \%$ & $16.4 \%$ \\
\hline $\begin{array}{l}\text { Termination Fee ( } \% \\
\text { of Enterprise Value) }\end{array}$ & $0.1 \%$ & $2.8 \%$ & $2.5 \%$ & $16.3 \%$ \\
\hline
\end{tabular}

Consistent with statutory requirements, the statistics show that use of special committees of independent directors is standard in MBO transactions. Of the $\mathrm{MBO}$ transactions sampled, $87.4 \%$ were approved by a special committee of independent directors. ${ }^{193}$ Majority of minority conditions are less frequently employed, however, and were utilized in only $32 \%$ of transactions. This is likely due to the preference of boards and managers to satisfy the statutory conflict of interest requirements through disinterested board approval rather than disinterested shareholder approval. The former is typically easier to obtain as it requires only approval of a small self-contained group of known individuals. When utilized, the threshold

${ }^{193}$ See supra Part III.C. 
requirement for majority of minority conditions varies, with $18.5 \%$ of transactions requiring an affirmative vote of the entire outstanding minority shareholder base, and $13.6 \%$ requiring only a majority of the voting minority. Moreover, only one of these transactions provides that the board cannot waive this condition when it is included. ${ }^{194}$

The use of go-shop provisions or pre-signing auctions also is not uniform. Go-shops are present in only $23.5 \%$ of transactions. As Panel B shows, the scope of go-shops varies, with a median period of thirty-five days. With respect to buyer protections in the form of lock-ups, the median termination fee is $3.2 \%$ of the transaction value, with a maximum of $16.4 \%$ and a minimum of $0.2 \%$ of the transaction value. In $80.9 \%$ of $\mathrm{MBO}$ transactions, the buyer was provided matching rights. Matching rights bestow on the initial buying group a contractual right to match a competing bid. ${ }^{195}$ The median period of matching rights in our sample of transactions is four days. These figures are comparable with public takeovers generally. During this time period, $78.9 \%$ of all public transactions with a value greater than $\$ 10$ million have matching rights. The median termination fee for this subset is $3.5 \%$ of transaction value.

Thus, with the exception of special committees, there are no uniform standards of shareholder procedural protections employed in MBOs. With respect to buyer protections, the lock-ups granted to these buy-out groups are similar to adoption rates in public takeovers. This may be due in part to contractual bargaining as well as the individual attributes of each transaction. However, it may also be a consequence of management's negotiating leverage in the takeover process and a board's inability to bargain for a more open bidding environment. This possibility is further examined econometrically in Part IV.C., where we control for these variables as well as for transaction characteristics.

\section{Table III. Sale Process and Litigation Outcomes}

Set forth in Table III are descriptive statistics for other process metrics associated with our sample of MBOs:

${ }^{194}$ These statistics are in contrast to Delaware law on the subject, which has favored use of non-waivable majority of minority conditions. See In re John Q. Hammons Hotels Inc. S'holders Litig., 2009 WL 3165613, at *12 (Del. Ch. Oct. 2, 2009), reprinted in 35 DEL. J. CORP. L. 621, $639-40(2010)$

${ }^{195}$ See Subramanian, supra note 59 , at 735. 
Table III

\begin{tabular}{|c|c|c|}
\hline \multicolumn{3}{|l|}{ Panel A: } \\
\hline & $\mathbf{N}$ & $\%$ \\
\hline \multicolumn{3}{|l|}{ Sale Process } \\
\hline $\begin{array}{l}\text { Formal } \\
\text { Auction }\end{array}$ & 39 & $38.6 \%$ \\
\hline $\begin{array}{l}\text { Informal } \\
\text { Auction }\end{array}$ & 2 & $2.0 \%$ \\
\hline $\begin{array}{l}\text { Negotiated } \\
\text { Transaction }\end{array}$ & 60 & $59.4 \%$ \\
\hline \multicolumn{3}{|l|}{$\begin{array}{l}\text { Litigation and } \\
\text { Outcomes }\end{array}$} \\
\hline $\begin{array}{l}\text { Transaction- } \\
\text { Related } \\
\text { Litigation } \\
\text { (Yes) }\end{array}$ & 79 & $76.7 \%$ \\
\hline \multicolumn{3}{|l|}{$\begin{array}{l}\text { Litigation } \\
\text { Settlement: }\end{array}$} \\
\hline None & 22 & $34.4 \%$ \\
\hline Disclosure & 18 & $28.1 \%$ \\
\hline $\begin{array}{l}\text { Disclosure / } \\
\text { Amendment } \\
\text { of Agreement }\end{array}$ & 16 & $25.0 \%$ \\
\hline $\begin{array}{l}\text { Increase in } \\
\text { Consideration } \\
\text { / Damages }\end{array}$ & 8 & $12.5 \%$ \\
\hline
\end{tabular}




\begin{tabular}{|l|c|c|c|c|c|}
\hline \multicolumn{7}{|l|}{ Panel B: } & N & Min & Mean & Median & Max \\
\hline $\begin{array}{l}\text { Auction: \# } \\
\text { Initial } \\
\text { bidders } \\
\text { contacted }\end{array}$ & 39 & 3 & 40 & 33 & 173 \\
\hline $\begin{array}{l}\text { Number } \\
\text { of Suits }\end{array}$ & 76 & 1 & 3 & 2 & 15 \\
\hline $\begin{array}{l}\text { Settlement } \\
\text { Value - } \\
\text { Attorney }\end{array}$ & 58 & $\$ 0.0$ & $\$ 1,247.8$ & $\$ 350.0$ & $\$ 29,250.0$ \\
$\begin{array}{l}\text { Fees } \\
\text { (\$000s) }\end{array}$ & & & & \\
\hline
\end{tabular}

When adequate information is disclosed.

It appears there is no uniformity for the sale process of these targets. Of the sampled transactions, $38.6 \%$ are executed via formal auction while $59.4 \%$ are negotiated transactions. In the case of auctions, the median number of bidders initially contacted was thirty-three. As previously noted, $44.1 \%$ of transactions are initiated by interested management or directors. Meanwhile, boards initiate the sale process $24.5 \%$ of the time. The sale process is initiated by a third-party bidder or investment bank in $31.4 \%$ of transactions.

In unreported statistics, we find that $15.5 \%$ of transactions fail to complete. This compares with $7.8 \%$ of all public takeover transactions with a transaction value greater than $\$ 10$ million announced during the time period for our sample. Competing bids were made in $12.8 \%$ of transactions. This compares to competing bids in $5.2 \%$ of all public takeovers with a transaction value greater than $\$ 10$ million during the same time period. Descriptively, this shows a more active and contestable market for MBOs. The higher level of contestability of MBOs is perhaps indicative of lower initial premiums or limited contractual lock-ups, which provide opportunities for bidders to make competing bids in greater proportion to the general takeover market.

Litigation can serve as a post-transaction announcement enforcement mechanism on MBOs. However, litigation can also be a costly nuisance 
brought on by entrepreneurial shareholder-plaintiff law firms. ${ }^{196}$ There is an experienced plaintiffs' bar that regularly initiates litigation involving public takeovers on behalf of shareholders. ${ }^{197}$ These firms will file multiple suits in a variety of transactions in order to obtain a quick settlement and attorney's fees. ${ }^{198}$

In the $\mathrm{MBO}$ context, we find high rates of litigation. At least one lawsuit is brought in $76.7 \%$ of transactions, and the median number of complaints filed in those suits is two. Consistent with the view that these suits are brought en masse for settlement purposes, we find a settlement is reached prior to transaction completion in $65.6 \%$ of all transactions with litigation. Only $12.5 \%$ of lawsuits, however, result in an award of monetary damage to shareholders. The remainder are dismissed or settled upon terms for disclosure or substantive amendment of the acquisition agreement.

Of the shareholder suits settled, $35.4 \%$ include an amendment of the acquisition agreement to provide substantive benefits to shareholders, specifically by way of an amendment to the merger agreement to increase contractual competitiveness or consideration. These types of litigation settlements can be viewed as providing an ex post facto check on a board process, provided, for example, heightened protections to shareholders, such as majority of minority conditions in transactions. Notably, and consistent with the attorney fees theory of this litigation, we find that $72.4 \%$ of suits settled or dismissed include an agreement on attorney fees. The median attorney fee awarded is $\$ 462,500$, with a maximum fee of $\$ 29.25$ million.

\section{Econometric Analysis}

In this subsection we conduct more robust econometric analysis of our sample to more fully explain the effect of process and the allocation of wealth in MBO transactions. Set forth in Table IV are ordinary least squares (OLS) regressions of offer premiums in MBOs against various process attributes and characteristics of MBOs. By testing these variables against offer premiums we can further unpack the drivers of wealth allocation in an

${ }^{196}$ See Elliott J. Weiss \& Lawrence J. White, File Early, Then Free Ride: How Delaware Law (Mis)Shapes Shareholder Class Actions, 57 VAND. L. REV. 1797, 1855-56 (2004)(describing a pattern of attorneys apparently filing suits in mergers primarily to seek fees rather than to help clients).

${ }^{197}$ See id.

${ }^{198} \mathrm{See} i d$. at 1828 (analyzing 104 Delaware shareholder-plaintiffs lawsuits in mergers and finding evidence of rapid and early complaint filings, suggesting opportunistic behavior by the plaintiffs' bar). 
MBO. ${ }^{199}$ All models include controls for time effects, transaction size, and industry effects through clustering of standard errors.

Table IV. Explaining the Final Offer Premium

Presented in Table IV are OLS regressions of final offer premium to target stock price on various process and contract terms sixty days before offer announcement. Only completed transactions with an offer price of at least five dollars per share are included. "Auction" equals one for auctions and zero for negotiated transactions. "Initiating Entity" equals zero for management, one for directors or investment banks, and two for third-party bidders. "Termination Fee" is the contract termination fee as a percent of transaction value, or zero if no termination fee is included in the contract. The years "2007-2009" indicate transactions announced in these years. "Competitive Contract" equals one if the contracting process contains at least one of the following: special committee of independent directors, go-shop provision, or majority of minority target shareholder approval required. "Matching Rights" equals one if the bidder is granted matching rights. "Freeze-out" equals one if management holds a controlling block of the target. "Substantive Benefit" equals one if legal review of the transaction imposed an amendment to the agreement or offer price revision. Standard errors are clustered at the target 3-digit SIC level, and p-values are reported in parentheses. "***", "**", and "*" represent statistical significance at the $1 \%, 5 \%$, and $10 \%$ levels, respectively.

Table IV

\begin{tabular}{|l|r|r|r|r|r|r|r|r|}
\hline & $\underline{(1)}$ & $\mathbf{( 2 )}$ & & $\mathbf{( 3 )}$ & & $\mathbf{( 4 )}$ \\
\hline Constant & 0.123 & & 0.124 & & 0.102 & & 0.117 & \\
\hline & $(0.379)$ & & $(0.373)$ & & $(0.478)$ & & $(0.392)$ & \\
\hline $\begin{array}{l}\text { Log } \\
\text { Transaction } \\
\text { Value }\end{array}$ & -0.010 & & -0.007 & & -0.008 & & -0.007 & \\
\hline & $(0.480)$ & & $(0.632)$ & & $(0.646)$ & & $(0.605)$ & \\
\hline
\end{tabular}

${ }^{199}$ For these purposes we limit the regression sample in Table IV to completed MBOs with a per share offer price of at least $\$ 5$ per share, consistent with practice in financial studies. 


\begin{tabular}{|c|c|c|c|c|c|c|c|c|}
\hline Auction & 0.041 & & 0.045 & & 0.073 & & 0.046 & \\
\hline & $(0.449)$ & & $(0.412)$ & & $(0.248)$ & & $(0.354)$ & \\
\hline $\begin{array}{l}\text { Initiating } \\
\text { Entity }\end{array}$ & 0.058 & * & 0.065 & ** & 0.060 & * & 0.058 & * \\
\hline & $(0.080)$ & & $(0.025)$ & & $(0.099)$ & & $(0.097)$ & \\
\hline $\begin{array}{l}\text { Termination } \\
\text { Fee }\end{array}$ & -0.516 & & -0.527 & & -0.054 & & -0.737 & \\
\hline & $(0.671)$ & & $(0.658)$ & & $(0.962)$ & & $(0.619)$ & \\
\hline $2007-2009$ & -0.117 & $* * *$ & -0.122 & *** & -0.116 & $* *$ & -0.120 & $* * *$ \\
\hline & $(0.006)$ & & $(0.002)$ & & $(0.033)$ & & $(0.010)$ & \\
\hline $\begin{array}{l}\text { Competitive } \\
\text { Contract }\end{array}$ & 0.157 & *** & 0.155 & $* * *$ & & & 0.152 & **** \\
\hline & $(0.000)$ & & $(0.001)$ & & & & $(0.002)$ & \\
\hline $\begin{array}{l}\text { Delaware } \\
\text { Target }\end{array}$ & & & -0.032 & & & & & \\
\hline & & & $(0.557)$ & & & & & \\
\hline \begin{tabular}{|l} 
Special \\
Committee
\end{tabular} & & & & & 0.142 & $* * *$ & & \\
\hline & & & & & $(0.008)$ & & & \\
\hline $\begin{array}{l}\text { Majority of } \\
\text { Minority }\end{array}$ & & & & & -0.028 & & & \\
\hline & & & & & $(0.304)$ & & & \\
\hline $\begin{array}{l}\text { Go-Shop } \\
\text { Provision }\end{array}$ & & & & & 0.017 & & & \\
\hline & & & & & $(0.741)$ & & & \\
\hline $\begin{array}{l}\text { Matching } \\
\text { Rights }\end{array}$ & & & & & -0.000 & & & \\
\hline & & & & & $(0.997)$ & & & \\
\hline
\end{tabular}




\begin{tabular}{|l|r|r|r|r|r|r|r|r|}
\hline Freeze-out & & & & & & & 0.036 & \\
\hline & & & & & & & $(0.766)$ & \\
\hline $\begin{array}{l}\text { Substantive } \\
\text { Benefit }\end{array}$ & & & & & & & & \\
\hline & & & & & & & $(0.624)$ & \\
\hline $\mathrm{N}$ & 62 & & 62 & 57 & & 62 & \\
\hline $\mathrm{R}^{2}$ & $19.62 \%$ & & $20.14 \%$ & & $20.19 \%$ & & $20.15 \%$ & \\
\hline & & & & & & & & \\
\hline
\end{tabular}

The results in Table IV provide evidence that increased procedural protections result in higher offer premiums in MBOs, and that the use of special committees of independent directors in particular is associated with higher offer premiums. In contrast, we find there is no relation between offer premiums and the presence or absence of a majority of minority condition or a go-shop provision. In unreported regressions we also find no relation between offer premium and the type of majority of minority condition (either a vote of the entire minority or majority of those present and voting), whether the majority of minority condition is waivable by the target board, and other types of procedural protections such as termination fee structure.

We find that offer premiums are also significantly related to the competitiveness of contracts. ${ }^{200}$ In our regressions this variable is positive and significant, indicating that higher offer premiums are associated with competitive contracts. The coefficient of the competitive contract variable is similar in magnitude to that of the special committee variable, indicating that much of the explanatory power in this variable may be driven by the special committee impact. Nonetheless, the results are both statistically and economically meaningful, implying that, on average, transactions approved by a special committee of independent directors provide target shareholders with a $14 \%$ higher offer premium.

The significance of the special committee variable in juxtaposition to these other process variables is likely due to the role a functioning and

\footnotetext{
${ }^{200}$ We define a "Competitive Contract" for these purposes as a contract containing any one of three variables: (1) negotiation by a special committee of independent directors, (2) a go-shop provision, or (3) a requirement that it be approved by a majority of the unaffiliated shareholders.
} 
independent special committee can play in these transactions. A special committee can independently negotiate these other measures as well as the offer price. A contract negotiated by a properly functioning independent special committee should equate with arm's-length bargaining for offer premium and contract terms. ${ }^{201}$

To further test the role of management and its relation to offer premiums, we also regress in Table IV offer premiums against the variable we term "Initiating Entity." This variable is determined by which party (management, board, investment bank or third-party) initiated the transaction. We obtained this information by reviewing the proxy statements and other transaction documents filed with the SEC for each MBO. As is reflected in Table IV, we find that premiums are significantly related to the type of initiating entity and that offer premiums are reduced when management is the initiating entity. Our findings are robust no matter the type of sale process used in the transaction, whether it is an auction or a negotiated transaction. This result supports the theory that an initial management bid can clear the playing field and skew the process towards a favorable management outcome. The announcement of an initial bid, either publicly or not, can skew the board process or perhaps drive off competing bidders who may competitively increase the offer price. This result is significant in all four columns and shows that even in the presence of a special committee or a competitive contract, offer premiums are negatively correlated with management initiation of the transaction.

Management's dominating effect in these circumstances and its effect on buy-out premiums was anecdotally illustrated in the 2010 buy-out of J.Crew Group Inc. by its management and two private equity firms: TPG Capital and Leonard Green \& Partners. ${ }^{202}$ In that case a special committee was formed while independent advisers were appointed. However, J. Crew's chief executive, Millard S. Drexler, waited seven weeks to inform the board he was discussing a buyout with the private equity firms TPG Capital and Leonard Green. At the last minute the buy-out group lowered its offer to $\$ 43$ per share from $\$ 45.50$, a price the J.Crew special committee accepted. ${ }^{203}$ Despite a litigation settlement which reduced the termination fee

${ }^{201}$ See William T. Allen, Independent Directors in MBO Transactions: Are They Fact or Fantasy?, 45 BUS. LAW. 2055, 2060 (1990) ("When a special committee's process is perceived as reflecting a good faith, informed attempt to approximate aggressive, arm's-length bargaining, it will be accorded substantial importance by the court.").

${ }^{202}$ See Evelyn Rusli, In J. Crew Buyout, an Effort to Gain a Retail Visionary, N.Y. TIMES DEALBOOK (Nov. 23, 2010, 9:49 PM), http://dealbook.nytimes.com/2010/1 1/23/in-j-crew-buyoutan-effort-to-gain-a-retail-visionary/.

${ }^{203}$ See Steven M. Davidoff, J.Crew Buyout Raises Questions, N.Y. TIMES DEALBOOK(Dec. 
and required approval by the unaffiliated shareholders, no competing bid arose. ${ }^{204}$ This may have been due in part to Millard S. Drexler's dominating position over the company and a need to keep him involved to continue J.Crew's success. $^{205} \mathrm{Mr}$. Drexler's actions also appear to have reduced the buy-out price and arguably pushed away other potential bidders, an effect we document.

Management in jurisdictions outside Delaware may also attempt to take advantage of a lower quality judiciary or legal regime to allocate offer premium to themselves. However, we find no relation between jurisdiction of incorporation and offer premium. This may be due to the lack of relation between litigation and bid failures, which we find in Table V, infra, or otherwise may be due to the normative protections a special committee provides. These normative protections may serve a similar function to court review; this is particularly true in light of our findings about the (lack of) effect of litigation on offer outcomes. In the fourth column of Table IV, we find no evidence that lawsuits resulting in substantive benefits (e.g., amendment of the agreement) produce higher offer premiums. Moreover, freeze-out transactions subject to review under the "entire fairness" doctrine are unrelated to offer premium. ${ }^{206}$ Thus, we conclude that in the MBO context, ex ante process and contract variables are at least as important in the protection of target shareholders as ex post facto court review.

The regressions thus far show that the presence of a special committee can result in higher offer premiums, while management participation can negatively affect these offer premiums. The relationship between offer premiums and process, however, does not fully reflect the power that process provides in terms of empowering shareholders or the role that process has in influencing MBO transaction outcomes. Higher procedural protections can provide shareholders the power to reject unduly low bids as well as allow for higher rates of competing bids.

To fully analyze both initial and final MBO outcomes and whether process does indeed influence these outcomes, we next assess whether the level of process can predict bid failure. Set forth in Table V are probit

10, 2010, 4:14 PM), http:/dealbook.nytimes.com/2010/12/10/j-crew-buyout-raises-questions/.

${ }^{204}$ See Steven M. Davidoff, J. Crew Buyout Settlement Still Leaves Questions, N.Y. TMMES DEALBOOK (Jan. 21, 2011, 3:00 PM), http://dealbook.nytimes.com/2011/01/21/j-crew-buyoutsettlement-still-leaves-some-questions/.

${ }^{205}$ Ronald Barusch, The J.Crew Buyout: Doing Everything Wrong, WALL ST. J. DEAL J. (Dec. 7, 2010, 8:58 AM), http://blogs.wsj.com/deals/2010/12/07/the-j-crew-buyout-doingeverything-wrong/.

${ }^{206}$ For these purposes, a freeze-out transaction is an MBO transaction with a merger structure where the buying group controls $50 \%$ or greater of the target's common stock. These transactions are therefore subject to "entire faimess" review under Kahn v. Lynch. See discussion supra notes 153-58 and accompanying text. 
regressions measuring bid failures against various process variables. For these purposes we run regressions in two categories to separate the drivers of bid failure in high premium versus low premium bids.

Table V. Predicting Failed Bids

In the following probit models of transaction outcomes, failed bids equal one and completed bids equal zero. The "Low Offer Premium" subsample includes transactions with a below-median premium of initial offer price to target price sixty days prior to offer announcement. The "High Offer Premium" subsample includes transactions with an above-median premium of initial offer price to target price sixty days prior to offer announcement. The years "2007-2009" indicate transactions announced in these years. "Competitiveness Index" is defined in Exhibit A. "Competing Bids" equals one if a transaction has competing bids and zero otherwise. "Lawsuit" equals one if the transaction involves shareholder litigation and zero otherwise. Standard errors are clustered at the target 3-digit SIC level, and p-values are reported in parentheses. "***", "**", and "*" represent statistical significance at the $1 \%, 5 \%$, and $10 \%$ levels, respectively.

\section{Table V}

\begin{tabular}{|c|c|c|c|c||c|c|c|c|}
\hline & \multicolumn{6}{|c|}{ Low Offer Premium } & \multicolumn{3}{|c|}{ High Offer Premium } \\
\hline & $(\mathbf{1})$ & & $\mathbf{( 2 )}$ & & $(\mathbf{3})$ & $(\mathbf{4})$ & \\
\hline Constant & -1.788 & $*$ & -2.375 & $*$ & -1.844 & $* * *$ & -2.918 & $* * *$ \\
\hline & $(0.089)$ & & $(0.057)$ & & $(0.010)$ & & $(0.000)$ & \\
\hline Log Transaction & 0.120 & & -0.117 & & 0.145 & & 0.259 & $*$ \\
\hline Value & $(0.451)$ & & $(0.542)$ & & $(0.229)$ & & $(0.075)$ & \\
\hline $2007-2009$ & 1.183 & $* * *$ & 1.549 & $* * *$ & 0.928 & & 0.910 & \\
\hline & $(0.003)$ & & $(0.002)$ & & $(0.126)$ & & $(0.221)$ & \\
\hline Competitiveness & 0.373 & $*$ & 0.331 & $*$ & -0.088 & & -0.058 & \\
\hline Index & $(0.052)$ & & $(0.082)$ & & $(0.722)$ & & $(0.801)$ & \\
\hline Competing Bids & & & 1.891 & $* * *$ \\
\hline
\end{tabular}




\begin{tabular}{|c|c|c|c|c|}
\hline & & $(0.009)$ & & $(0.000)$ \\
\hline Delaware Target & & 0.287 & & -1.051 \\
\hline & & $(0.583)$ & & $(0.083)$ \\
\hline Lawsuit & & -0.252 & & 0.417 \\
\hline & & $(0.744)$ & & $(0.469)$ \\
\hline $\mathrm{N}$ & 52 & 52 & 49 & 49 \\
\hline $\mathrm{R}^{2}$ & $22.49 \%$ & $41.15 \%$ & $11.06 \%$ & $46.29 \%$ \\
\hline
\end{tabular}

To fully test the effect of contract competitiveness on bid failures, we construct an index of contract competitiveness to measure the protectiveness of a contract. This index is set forth in Exhibit A and is designed to measure process and contract competitiveness terms. The key process measures included are the utilization of a special committee, go-shop, majority of minority condition, tender offer, large termination fee, or auction, as well as whether management was the initiating entity. The contract competitiveness index is then adjusted up or down depending upon the presence of these measures and whether they foster protection of unaffiliated shareholders. Exhibit A sets forth in greater detail the methodology for construction of the index.

After constructing the index, we regress a binary variable that captures bid outcome (one representing failed bids and zero representing completed bids) against the contract competitiveness index and other controls for each MBO offer premium sub-group. The regressions show that for the high offer premium group, contract structure does not predict failed bids. This is an intuitive result, as these MBOs were announced with initially competitive offer premiums. In contrast, for the low offer premium group, more competitive contracts are associated with a greater incidence of failed bids. In other words, the more competitive a contract is, the more likely a low premium offer will fail. These findings support the conclusion that shareholders are able to reject "bad" offers if the process structure provides them power to do so. Conversely, we find that a low competitiveness index for the contracting process makes it more difficult for target shareholders to successfully fend off lower offers.

We also find (in unreported regressions) that litigation is more likely to be filed in both larger transactions and when the initial offer premium is lower. At first blush, this would imply that litigation can serve as a monitoring device. We do not find any relation, however, between settlement results and offer premiums. In particular, low offer premium 
transactions are not associated with litigation settlements that result in an increased offer price. In addition and contrary to the thesis that litigation can serve as an effective monitor of MBOs, we also find in unreported regressions that lawsuits are more likely in deals with special committees and majority of minority conditions.

\section{POLICY PRESCRIPTIONS}

We find that process matters in MBOs. Special committees of independent directors appear to significantly influence the wealth effects of MBOs and produce increased offer premiums for target shareholders. We also find that shareholders are allocated a lesser amount of an offer premium when management is the initiator of the $\mathrm{MBO}$ as opposed to a board or third party. Finally, contract structure has a statistically significant effect on MBO outcomes; among potentially coercive offers, we find that the more competitive the contract is in terms of contractual protections, the higher the rate of bid failure. Our findings support the conclusion that shareholders can and do resist low offer deals when they are provided the means to do so.

These findings lead to both normative and legal policy conclusions for the future conduct and regulation of MBOs. Initially, with our descriptive data we can propose a definition of MBOs and MBIs for future use. We define an $\mathrm{MBO}$ as a transaction where management is the organizing or controlling party for purposes of the buy-out. We define an MBI as a transaction where management is a participant but is not the organizing or controlling party. We define "controlling" as the party orchestrating and negotiating the transaction. Under these definitions, $45 \%$ of our sampled transactions are MBOs, and the rest MBIs. We believe this broader definition of $\mathrm{MBO}$ is more attuned to the characteristics associated with MBOs, which are typified as management acquisitions.

We find that a key characteristic driving wealth effects in MBOs is whether management initiated the transaction. It appears that both the initial head start management provides itself and the clearing nature of its bid have important implications for the regulation of MBOs. While the level of managerial ownership in the target is unrelated to ultimate offer premiums, even if it is a controlling interest, its correlative relationship could be complicated by differing economic incentives following close of the transaction and stemming from subsequent change in interested director and officer ownership. Thus, the identity of the initiating entity provides a useful reference point from which to evaluate the ensuing negotiations and the potential for participation by outside entrants. Our following legal policy recommendations are driven by this finding and also our related finding that 
special committees of independent directors can function effectively to produce higher offer premiums for MBO shareholders. ${ }^{207}$

The law should encourage the formation of a special committee in MBOs regardless of the size of management's stake. As theorized in the freeze-out context, a special committee can function as an independent bargaining force. ${ }^{208}$ It can independently negotiate an arm's-length equivalent transaction. In this regard, it appears that laws which do not require special committee approval-like Florida's - are deficient. Our findings indicate that in order for a special committee to function effectively, it should have independent advisors and the unfettered power to approve or reject the transaction. This provides a committee with the ability to actively and effectively negotiate an MBO transaction.

We believe that the current Delaware case-law, which provides that conflict of interest transactions are subject to business judgment deference, as outlined in the Wheelabrator decision, is an appropriate standard subject to the following caveat: Courts should refuse to apply the business judgment rule to a board's agreement to an MBO when the contract that results from this negotiation is not a competitive one. Special committees appear to be the driver of offer premiums, but management appears to have the ability to influence offer premiums by initiating and affecting the MBO process. To alleviate this pressure, courts should be particularly attuned to the presence and performance of special committees. Special committees that are advised by independent advisors and that negotiate competitive contracts which include a majority of minority condition and other indicia of competitiveness should be presumed to function independently. ${ }^{209}$ In such a circumstance, the decision of the board to enter into the transaction should be subject to the business judgment rule. The scrutiny we propose on the contractual process is effectively an assessment of whether the independent special committee of directors was actually independent in person and function. It also has the virtue of keeping courts out of thorny issues of assessing fair price, an

\footnotetext{
${ }^{207}$ We leave for another paper the question of whether MBOs have social utility in and of themselves, and whether this reallocation of shareholder premium would otherwise unduly inhibit these transactions.

${ }^{208}$ See supra notes $153-60$ and accompanying text.

${ }^{209}$ We do not address how courts should scrutinize any defensive actions taken by a special committee, such as the adoption of a poison pill. The focus of our study is not on the board's decision to enter into an MBO transaction, but rather the protections used when the board agrees to such a transaction. We thank George Geis for pointing out this possibility. George S. Geis, Internal Poison Pills, 84 N.Y.U. L. REV. 1169, 1202 (2009).
} 
inherently subjective standard of review that depends upon a court's assessment of valuation techniques. ${ }^{210}$

Our suggested review is particularly appropriate when management initiates the transaction. Our findings implicate adoption of a sliding scale approach by judges reviewing MBO transactions. The role and function of a special committee should be provided more judicial deference when there are independent measures of bid premium and competitiveness present, including when non-management parties initiate the transactions. The scale of deference should weigh the competitiveness of contracts negotiated by the special committee as indicia of the effectiveness and independence of the special committee. Courts should scrutinize lock-ups and other contractual protections; and if the entirety of the situation indicates that the committee has not negotiated a competitive contract, it should refuse to defer to the independent committee's approval of the transaction. In such a circumstance, the court itself would review the transaction under the "entire fairness" standard.

In the $\mathrm{MBO}$ context, we similarly believe that such deference is appropriate when protections are present, rather than substitution of "entire fairness" review. This recommendation jibes with our findings that transactions under "entire fairness" review in our sample are unrelated to higher offer premiums. Our alternative standard also permits a court to conduct its own review of process without the more extended review of price that "entire fairness" requires. These findings can be analogized to other conflict situations outside of takeovers-mechanisms which empower independent directors and inform their decisions are theoretically likely to mitigate conflicts. Our findings support such a split market-based solution supported by substantive judicial review when a market failure is indicated.

We recognize that our findings show that offer premiums are lower when management is the initiating entity, even in the presence of a special committee and other procedural protections. We are hesitant to use this finding, however, to justify mandatory "entire fairness" review of $\mathrm{MBO}$ transactions by a court given that we find no correlation between this variable and offer premiums. Nor are we ready to recommend that these transactions be banned, not in the absence of further evidence that they are wealth destroying. Moreover, we cannot think of a mechanism that would prevent management from eluding such a per se ban on these transactions when management initiates them as opposed to permitting them in other

${ }^{210}$ See Steven M. Davidoff, Fairness Opinions, 55 AM. U. L. REV. 1557, 1585 (2006) (discussing the subjectivity inherent in valuation and court decisions with respect thereto). 
circumstances. Instead, we cautiously advocate more vigorous judicial scrutiny of procedural protections, in this circumstance as well as the entire process, to ensure that shareholders are provided an adequate market check. We also believe our findings provide future special committees with information to negotiate higher offer premiums. Nonetheless, this is an area which should remain the focus of future study and monitoring.

Courts should be aware that in unreported regressions we also found that granular mechanisms, such as the form and scope of non-waivable majority of minority conditions, do not appear to matter as much as the existence of the condition itself. This may be due to the fact that the mere presence of these protections signals to the market the ability of shareholders to fend off low premium bids. It also may be because the market does not appreciate the utility of these mechanisms. Further observation and study of transactions is required to more definitively prove the value of these mechanisms at a more specific level.

Finally, we view the adoption of this standard of review as effectively imposing a more vigorous application of the standard annunciated in Revlon, Inc. v. MacAndrews \& Forbes Holdings, Inc. ${ }^{211}$ In that case, as subsequently interpreted by the Delaware courts, the Delaware Supreme Court held that a board decision involving a change of control or a company breakup would be subject to strict scrutiny because the inherent conflict the board faced in the takeover decision. ${ }^{212}$ Revlon duties require the board to obtain the "highest price" reasonably available. ${ }^{213}$ These duties currently apply to MBO transactions if there is no controlling shareholder interest in existence prior to the announcement of the MBO transaction. ${ }^{214}$

As subsequently interpreted, Revlon duties have allowed for boards to agree, to significant measures, to lock-up and protect an initially agreed-to transaction. ${ }^{215}$ In this regard, Delaware courts have subjected these lock-ups to objective analysis for reasonableness in reference to the facts and circumstances of the transaction. ${ }^{216}$ This analysis, however, does not capture

${ }^{211}$ Revlon, Inc. v. MacAndrews \& Forbes Holdings, Inc., 506 A.2d 173, 180, 182 (Del. 1986).

${ }^{212} I d$.

${ }^{213} \mathrm{Id}$. at 182 .

${ }^{214}$ Cf. In re Cysive, Inc. S'holders Litig., 836 A.2d 531, 547 (Del. Ch. 2003) (holding that when hearing a stockholder challenge to an MBO transaction where there exists a controlling shareholder, the proper standard of review is entire fairness).

${ }^{215}$ See, e.g., In re J.P. Stevens \& Co. S'holders Litig., 542 A.2d 770, 781-82 (Del. Ch. 1988) ("Revlon, however, does not purport to restrict the powers of a disinterested board from entering into agreements of the kind here under attack if, in doing so, the board acts in good faith and with appropriate care.").

${ }^{216}$ See Paramount Commc'ns Inc. v. QVC Network Inc., 637 A.2d 34, 45 (Del. 1994). 
the more searching review for the variables we find are important in determining the outcomes and wealth effects of MBOs. Thus, for MBOs we propose that Revlon should continue to be applied as appropriate, but that the higher scrutiny we outline is desirable to regulate the greater conflict, namely that management is on both sides of the transaction.

The standard of review we propose also largely jibes with current Delaware law in the case of freeze-outs, as addressed in $C N X,{ }^{217}$ and in the case of differential benefits to a controlling shareholder in a takeover, as addressed in the Hammons decision. ${ }^{218}$ In those circumstances, the courts set forth substantive legal standards requiring both independent special committees approval of the transaction and majority of minority conditions in order for the transaction to avoid ex post facto court review for "entire fairness." ${ }^{219}$ Because the bidding itself could be controlled by the controlling shareholders, these rulings mandated a procedural protection regime which empowered shareholders without focus on provisions that encouraged competitive bidding. ${ }^{220}$

However, in an $\mathrm{MBO}$ as opposed to a freeze-out, a per se requirement of a majority of minority condition appears inappropriate since in MBO transactions management often lacks a controlling stake in the target. ${ }^{221} \mathrm{~A}$ majority of minority condition is therefore simply a regular majority voting requirement. In contrast, a special committee requirement can function in all circumstances. Therefore, we believe that a special committee should be required in all circumstances when management is a participant in the buyout group. Beyond this requirement, we do not believe there should be per se procedural requirements other than court scrutiny of contractual competitiveness on a sliding scale. This is due to the heterogeneous nature of MBOs and the need for courts to exercise discretion in assessing the competitiveness of the MBO negotiation. ${ }^{222}$

Our recommendation fits with Delaware's penchant for substitution of procedural mechanisms mimicking arm's-length bargaining for ex post facto court review. When a special committee negotiates competitive contracts

${ }^{217}$ In re CNX Gas Corp. S'holders Litig., 4 A.3d 397, 406-14 (Del. Ch. 2010).

${ }^{218}$ In re John Q. Hammons Hotels Inc. Sholders Litig., 2009 WL 3165613, at *12 (Del. Ch. Oct. 2, 2009), reprinted in 35 DEL. J. CORP. L. 621, 639-40 (2010); see also supra Part III.B.

${ }_{219}^{21}$ In re CNX Gas Corp., 4 A.3d at 400, 405-414; In re John Q. Hammons Hotels, 2009 WL 3165613 , at *12-*13.

${ }^{220} \mathrm{Id}$. at *12. We note that our findings as to the explanatory power of special committees versus "entire fairness" review also provide mild support for the rulings in both of these cases.

${ }^{221}$ See discussion supra Part IV.B.

${ }^{222}$ In the context of Delaware law, this would mean making mandatory section 144(a) of the Delaware General Corporation Law, which allows for approval of conflicted transactions by the independent directors. DEL. CODE ANN. tit. 8, § 144(a) (2001). 
similar in composition to a high scoring contract on the contract competitive index, this can offset low bid premiums and serve as a market check of the MBO proposal. This replicates the bargaining which theoretically occurs in takeover transactions with outside third parties. In such a circumstance, searching court inquiry is unnecessary absent other defects in the process, in deference to these market mechanisms. These conclusions also provide normative guidance for special committees of independent directors. Lawyers and others who advise these committees should be aware of the perils of non-competitive contracts, and should negotiate in light of these findings, particularly our finding that management initiation of the MBO transaction can result in lower offer premiums.

Our findings also inform a judicial approach to shareholder litigation in the MBO context. While we find that there is no effect of shareholder litigation on offer premiums or bid outcomes, we do not believe that this means shareholder litigation is wholly ineffective in these situations. Rather, the threat of this litigation may serve to enforce and enhance the bargaining of contracts and offer premiums. Litigation can theoretically serve as a costeffective monitoring device. The majority of costs in MBO litigation appear to be associated with attorneys' fee awards typically agreed to in settlements of MBO-associated litigation. Descriptively, these fees do not appear inordinate relative to deal size, on average, when they are perceived as payment for such monitoring. This finding also reinforces the decision of then-Vice Chancellor Strine in In re Cox Communications ${ }^{223}$ and that of other Delaware Court of Chancery judges, scrutinizing attorney fee settlements to ensure that they adequately compensate, and do not overcompensate, for the benefits such litigation has provided. ${ }^{224}$ We recognize the inherent difficulty in a judge's capacity to effectively monitor attorney's fees and assess the contribution of law firms in any settlement. The effect of shareholder litigation in MBOs is also a subject for further study.

\section{CONCLUSION}

In order to study the wealth effects of MBOs and the role of process we examined $103 \mathrm{MBO}$ transactions announced from 2003 to 2009 . We

${ }^{223}$ In re Cox Commc'ns S'holders Litig., 879 A.2d 604, 605, 635, 641-42 (Del. Ch. 2005).

${ }^{224}$ See, e.g., Brinckerhoff v. Texas E. Prod. Pipeline Co., 986 A.2d 370, 373-74, 396 (Del. Ch. 2010) (approving settlement and reducing the attorneys fees awarded to plaintiffs' attorneys from $\$ 19.5$ million to $\$ 10$ million in connection with two actions related to an acquisition transaction). Award of shareholder fees is sometimes related to jurisdictional considerations and the need for Delaware to retain lawsuits in its jurisdiction. Here, the current level of shareholder attorneys awards that Delaware has been awarding appear equivalent to other jurisdictions. 
have found that there is "value" in process. MBO offer premiums are positively associated with competitive contracts and the existence of special committees. Bid failure rates among low premium transactions are associated with competitive contracts. Our findings provide nuanced support to those who both criticize and support MBOs. We find evidence for the theory that management can unduly influence the buy-out process through timing and affecting it to their personal benefit. However, our findings also support those who advocate process mechanisms to cure this deficit and who assert that allowing for more open and competitive bidding can serve as a check on management MBO offers with low premiums. ${ }^{225}$ In addition, we find that ex ante procedural protections in MBOs affect the offer premium, while freeze-out transactions subject to review under the "entire fairness" doctrine are unrelated to offer premium. Our results support a cautious approach and rigorous application of current Delaware law to permit courts to more vigorously scrutinize MBO transactions for procedural competitiveness, particularly when management initiates the MBO transaction.

\section{Exhibit A: Competitiveness Index}

\section{COMPETITIVENESS INDEX CONSTRUCTION:}

$$
\begin{aligned}
& \text { Competitiveness Index }=\text { Special } \\
& \text { Committee + Go-Shop + Majority of } \\
& \text { Minority - Tender Offer - (Termination } \\
& \text { Fee }>3 \%)+ \text { Initiating Entity + Auction. }
\end{aligned}
$$

For these purposes, (1) "Majority of Minority Condition" refers to a condition requiring the approval of a majority of unaffiliated shareholders; (2) "Go-Shop" is defined as a provision allowing a target a pre-specified number of days to solicit third party bidders after announcement of the transaction; (3) "Special Committee" is a special committee of independent directors formed to consider the transaction; (4) "Auction" is a preannouncement, organized auction process; (5) "Tender Offer" is an acquisition conducted by a first step tender offer and back-end merger as opposed to a one-step merger transaction; (6) "Termination Fee (>3\%)" is a termination fee payable by a target that is greater than $3 \%$ of the total

\footnotetext{
${ }^{225}$ We should note a limitation of our findings: we do not make normative judgments on the appropriate allocation of premium and whether this premium is something target shareholders are more entitled to in comparison to those transactions.
} 
transaction value; (7) "Initiating Entity" refers to the party that first proposed the transaction, whether in a public announcement or through negotiations with the board of directors. For each of the above mechanisms and terms we add the respective incremental value to the index if the item is protective of target shareholders, empowers target shareholders to reject the MBO transaction, or encourages competitive bidding. For each of the above mechanisms and terms which detracts from these effects we subtract one unit from the index. The resulting index can be summarized as follows:

Majority of Minority Condition +1

Go-Shop +1

Special Committee +1

Auction +1

Tender Offer -1

Termination Fee $(>3 \%)-1$

Initiating Entity: Management 0 ,

Directors or Investment Bank +1 , Third

Party +2 